Article

\title{
Pseudomonas bijieensis Strain XL17 within the P. corrugata Subgroup Producing 2,4-Diacetylphloroglucinol and Lipopeptides Controls Bacterial Canker and Gray Mold Pathogens of Kiwifruit
}

\author{
Md. Arshad Ali ${ }^{1}{ }^{\mathbb{D}}$, Jinyan Luo ${ }^{2}$, Temoor Ahmed ${ }^{1}{ }^{\mathbb{C}}$, Jiannan Zhang ${ }^{1}$, Ting Xie ${ }^{1}$, Dejiang Dai ${ }^{3, *}$, Jingyong Jiang ${ }^{4}$, \\ Jie Zhu ${ }^{5}$, Sabry Hassan ${ }^{6}\left(\mathbb{D}\right.$, Jamal A. Alorabi ${ }^{6}$, Bin Li ${ }^{1}$ (D) and Qianli An ${ }^{1, *(D)}$
}

check for updates

Citation: Ali, M.A.; Luo, J.; Ahmed, T.; Zhang, J.; Xie, T.; Dai, D.; Jiang, J.; Zhu, J.; Hassan, S.; Alorabi, J.A.; et al. Pseudomonas bijieensis Strain XL17 within the P. corrugata Subgroup Producing 2,4-Diacetylphloroglucinol and Lipopeptides Controls Bacterial Canker and Gray Mold Pathogens of Kiwifruit. Microorganisms 2022, 10, 425. https://doi.org/10.3390/ microorganisms10020425 Academic Editors: Jacob G. Malone and Rafael Rivilla

Received: 15 December 2021 Accepted: 10 February 2022 Published: 12 February 2022

Publisher's Note: MDPI stays neutral with regard to jurisdictional claims in published maps and institutional affiliations.

Copyright: (C) 2022 by the authors. Licensee MDPI, Basel, Switzerland. This article is an open access article distributed under the terms and conditions of the Creative Commons Attribution (CC BY) license (https:// creativecommons.org/licenses/by/ $4.0 /)$.
1 State Key Laboratory of Rice Biology, Ministry of Agriculture Key Laboratory of Molecular Biology of Crop Pathogens and Insect Pests, Key Laboratory of Biology of Crop Pathogens and Insects of Zhejiang Province, Institute of Biotechnology, College of Agricultural and Biotechnology, Zhejiang University, Hangzhou 310058, China; alibau201@gmail.com (M.A.A.); temoorahmed@zju.edu.cn (T.A.); 21916084@zju.edu.cn (J.Z.); 22016086@zju.edu.cn (T.X.); libin0571@zju.edu.cn (B.L.)

2 Department of Plant Quarantine, Shanghai Extension and Service Center of Agriculture Technology, Shanghai 201103, China; toyanzi@126.com

3 Station for the Plant Protection \& Quarantine and Control of Agrochemicals Zhejiang Province, Hangzhou 310004, China

4 Taizhou Academy of Agricultural Sciences, Linhai 317000, China; jjy5971@163.com

5 Wenzhou Station of Plant Protection, Soils and Fertilizers, Wenzhou 325000, China; jane1979888@126.com

6 Department of Biology, College of Science, Taif University, P.O. Box 11099, Taif 21944, Saudi Arabia; hassan@tu.edu.sa (S.H.); dr.jamal.a@gmail.com (J.A.A.)

* Correspondence: 13958041692@163.com (D.D.); an@zju.edu.cn (Q.A.)

\begin{abstract}
Kiwifruit worldwide suffers from the devastating diseases of bacterial canker caused by Pseudomonas syringae pv. actinidiae (Psa) and gray mold caused by Botrytis cinerea. Here, an endophytic bacterium XL17 isolated from a rape crown gall was screened out for its potent antagonistic activities against Psa and B. cinerea. Strain XL17 and its cell-free culture filtrate (CF) inhibited the growth of Psa and B. cinerea, Psa-associated leaf necrosis, and B. cinerea-associated kiwifruit necrosis. Electron microscopy showed that XL17 CF could damage the cell structures of Psa and B. cinerea. Genome-based taxonomy revealed that strain XL17 belongs to Pseudomonas bijieensis within the $P$. corrugata subgroup of the $P$. fluorescens species complex. Among the P. corrugata subgroup containing 31 genomospecies, the presence of the phl operon responsible for the biosynthesis of the phenolic polyketide 2,4-diacetylphloroglucinol (DAPG) and the absence of the lipopeptide/quorum sensing island can serve as the genetic marker for the determination of a plant-protection life style. HPLC detected DAPG in extracts from XL17 CF. MALDI-TOF-MS analysis revealed that strain XL17 produced cyclic lipopeptides of the viscosin family and orfamide family. Together, phenotypic, genomic, and metabolic analyses identified that $P$. bijieensis XL17 producing DAPG and cyclic lipopeptides can be used to control bacterial canker and gray mold pathogens of kiwifruit.
\end{abstract}

Keywords: biocontrol; Pseudomonas syringae pv. actinidiae; Botrytis cinerea; DAPG; cyclic lipopeptides

\section{Introduction}

The genus Pseudomonas is one of the most complex and diverse genera among Gramnegative bacteria and consists of more than 300 species described to date (https:/ / lpsn. dsmz.de/genus/pseudomonas, accessed on 2 October 2021) [1]. Pseudomonas is ubiquitous in aquatic and terrestrial environments and in association with diverse hosts including plants and animals [1,2]. Among plant-associated Pseudomonas, both pathogenic and beneficial strains are reported in the same or different species. For example, the $P$. syringae species complex contains plant pathogens of a wide range of plant species [3] while in 
the P. fluorescens species complex, multiple species are recognized as pathogens (such as P. corrugata and P. mediterranea) and plant growth-promoting bacteria (such as P. brassicacearum, P. chlororaphis, and P. protegens) [2].

Kiwifruit (Actinidia chinensis) is native to China and is a nutrient-dense fruit becoming popular worldwide [4,5]. Kiwifruit is susceptible to various pathogens that cause diseases at different growth stages, as well as after harvest. The bacterial canker disease caused by Pseudomonas syringae pv. actinidiae (Psa) is the most prevalent and devastating pandemic disease of kiwifruit $[6,7]$. The symptoms include necrotic leaf spots surrounded by a chlorotic margin, twig die-back, blossom necrosis, reddening of the lenticels, and bleeding cankers on the trunk and the leader with a whitish to orange ooze [6]. The gray mold disease caused by Botrytis cinerea is the most prevalent and devastating postharvest disease of kiwifruit, accounting for up to $30 \%$ of total postharvest losses in extreme cases [8,9]. Gray mold generally starts at the stem end of kiwifruit and progress evenly toward the distal part. The infected areas of the fruit are darker than the healthy parts. The white or gray mycelia and spores may be seen in affected areas with dark green and water-soaked lesions in internal tissues [9].

No curative approaches have been developed for management of the two devastating diseases of kiwifruit $[7,8]$. Copper compounds (e.g., copper hydroxide and copper sulphate) and antibiotics (e.g., streptomycin and kasugamycin) have been used to control the bacterial canker disease with limited success $[10,11]$. Psa has developed resistance to both copper and streptomycin [10]. Likewise, B. cinerea has also developed resistance to fungicides along with the fungicide application to control the gray mold disease $[12,13]$. Moreover, continuous applications of the chemical pesticides contaminate fruits, threaten human health, and pollute environments [14]. Therefore, integrated managements for the sustainable production of kiwifruit are in progress, including the development of resistant cultivars and pollinators, optimization of cultural practices, equilibrated plant nutrition, precise scheduled spray treatments with effective and eco-friendly antimicrobial agents, compounds inducing plant systemic resistance, and biocontrol agents $[6,8,14,15]$.

Psa can survive on the surface of plant organs including leaves, twigs, buds, flowers, and fruits $[16,17]$ and enter the plant through natural openings (e.g., stomata and lenticels) or wounds (e.g., fruit abscission scars or fresh cuts) and undergo a transition from the epiphytic phase to the endophytic phase, then move in plant tissues via apoplast and to different organs preferentially through xylem [18-21]. B. cinerea can infect leaves, stems, flowers, and fruits and live as endophytes before causing disease [22].

Endophytes can colonize the same sites as pathogens and compete against pathogens for niches and nutrition, and may directly inhibit pathogen growth or induce plant defense to reduce pathogen infection, and thus can be effective biocontrol agents to control plant diseases [23]. To develop effective biocontrol agents with endophytes, we screened endophytic bacteria from various plants based on broad-spectrum antimicrobial activities [24]. We found a strain which was isolated from a surface-sterilized crown gall of a rape plant and showed exceptional antagonistic activities against Psa and multiple fungal pathogens including B. cinerea. Here, we identify this strain belonging to P. bijieensis within the P. corrugata subgroup of the $P$. fluorescens species complex and determine its biocontrol potentials and mechanisms against Psa and fungal pathogens.

\section{Materials and Methods}

\subsection{Microbial Strains}

Psa strain ML2-12 was isolated from a bacterial canker stem of a kiwifruit plant grown in Taizhou, China. Botrytis cinerea strain B05.10 is a haploid strain derived from the monoascospore isolate SAS56 from grapevine (Vitis vinifera) [25].

Bacterial strain XL17 was isolated from a surface-sterilized crown gall of a rape plant (Brassica napus) grown in Hangzhou, China. The crown gall was surface-sterilized by $70 \%$ ethanol for $1 \mathrm{~min}$ and 5\% sodium hypochlorite for $5 \mathrm{~min}$ and washed with sterile water six times, then ground in $1 \mathrm{~mL}$ of sterile water. The homogenate was streaked on a 
modified yeast extract-mannitol agar (yeast extract $0.08 \mathrm{~g}$, mannitol $1.0 \mathrm{~g}, \mathrm{~K}_{2} \mathrm{HPO}_{4} 0.25 \mathrm{~g}$, $\mathrm{KH}_{2} \mathrm{PO}_{4} 0.25 \mathrm{~g}, \mathrm{MgSO}_{4} \cdot 7 \mathrm{H}_{2} \mathrm{O} 0.2 \mathrm{~g}, \mathrm{NaCl} 0.1 \mathrm{~g}$, agar $15 \mathrm{~g}$ per liter; $\mathrm{pH} 7.0$ ) and incubated at $30{ }^{\circ} \mathrm{C}$ for $7 \mathrm{~d}$. Bacterial colonies showing different morphologies were purified by streaking. Purified bacteria were cultured in LB medium (yeast extract $5 \mathrm{~g}$, tryptone $10 \mathrm{~g}$, and $\mathrm{NaCl}$ 10 g per liter; $\mathrm{pH} 7.0)$ and then preserved with $15 \%(v / v)$ glycerol at $-80^{\circ} \mathrm{C}$.

\subsection{Assays of Antimicrobial Activities for Strain XL17}

Bacterial isolates from the surface-sterilized crown gall were screened against fungal pathogens by the bacteria-fungi confrontation assay on potato dextrose agar (PDA) as previously described [24]. Bacterial strains showing potent antifungal activity were selected and further screened for antibacterial activity against Psa by the overlay culture assay on LB agar [26]. Strain XL17 was screened out for its potent antagonistic activities against fungal pathogens and Psa.

Strain XL17 was cultured in LB broth at $30{ }^{\circ} \mathrm{C}$ for $48 \mathrm{~h}$. The culture was adjusted to approximately $1 \times 10^{8}$ colony forming unit $(\mathrm{CFU}) \cdot \mathrm{mL}^{-1}$ with sterile ultrapure water and centrifugated at room temperature. The supernatant was filtered through a sterile $0.22 \mu \mathrm{m}$ filter and used as the culture filtrate (CF). The CF was added into LB medium to a final concentration of $10 \%, 15 \%$, and $20 \%(v / v)$.

The effect of CF on the growth of $B$. cinerea was examined in potato dextrose broth (PDB) (potato infusion $200 \mathrm{~g}$, glucose $20 \mathrm{~g}$ per liter; $\mathrm{pH}$ 5.6) according to [27]. A $5 \mathrm{~mm}$ plug of $B$. cinerea was added into $50 \mathrm{~mL}$ of PDB containing $10 \%, 15 \%$, or $20 \%(v / v)$ CF and kept at $28{ }^{\circ} \mathrm{C}$ for $7 \mathrm{~d}$. Fungal mycelia were obtained after filtering with a filter paper (Sinopharm Chemical Reagent Co., Ltd., Shanghai, China) and dried in an oven at $65^{\circ} \mathrm{C}$ to a constant weight. The experiment was done tree times with three replications for each treatment.

The effect of CF on the growth of Psa was examined in LB broth containing 10\%, $15 \%$, or $20 \%(v / v)$ of CF in a 96-well microplate (Corning-Costar Corp., Corning, NY, USA). Psa strain ML2-12 was cultured in liquid LB medium for $16 \mathrm{~h} ; 10 \mu \mathrm{L}$ of the Psa culture was added into each microplate well. LB broth containing CF (200 $\mu \mathrm{L})$ was added into microplate wells. LB broth without CF was used as control. The microplate was incubated at $30{ }^{\circ} \mathrm{C}$ for $24 \mathrm{~h}$ and the optical density at $600 \mathrm{~nm}$ (OD600) was measured with a SpectraMax spectrophotometer (Molecular Devices, Sunnyvale, CA, USA). The experiment was done three times with three replications for each treatment.

\subsection{Scanning and Transmission Electron Microscopy on the Structure of Psa and B. cinerea}

Blocks of 7-day-old B. cinerea mycelia grown on PDA alone or PDA containing $20 \%$ CF of strain XL17 were prepared for scanning electron microscopy (SEM) and transmission electron microscopy (TEM) as previously described [24]. Psa grown for $24 \mathrm{~h}$ in LB broth or LB containing $20 \%$ CF of strain XL17 was precipitated by centrifugation and then prepared for SEM and TEM as previously described [24].

\subsection{Leaf Assay of Control Efficacy on Psa}

The biocontrol potentials of XL17 and its CF against Psa were tested with detached leaves. Healthy leaves of similar sizes of kiwifruit plants (Actinidia chinensis var. deliciosa 'Hayward') were collected from the orchard. Leaves were surface sterilized by immersing in $70 \%$ ethanol for $1 \mathrm{~min}, 1.5 \%$ sodium hypochlorite for $1 \mathrm{~min}$, and washing with sterile water six times [18]. The sterilized leaves were air dried inside a clean bench and the backside was cross marked with a sterilized needle. Each leaf was kept on a moistened filter paper inside a $15 \mathrm{~cm}$ petri dish. A drop $(20 \mu \mathrm{L})$ of XL17 culture $\left(1 \times 10^{8} \mathrm{CFU} \cdot \mathrm{mL}^{-1}\right), \mathrm{XL17} \mathrm{CF}(10 \%$, $15 \%$, or $20 \%$ in sterile water), streptomycin sulphate $\left(65 \mu \mathrm{g} \cdot \mathrm{mL}^{-1}\right)$ [28], or sterile water (control) was dropped on the cross marked area and air-dried. Then, $20 \mu \mathrm{L}$ of Psa culture $\left(1 \times 10^{8} \mathrm{CFU} \cdot \mathrm{mL}^{-1}\right)$ was dropped on the same cross marked area. Only sterile water was used as negative control while Psa culture with sterile water was used as positive control. The leaves were kept in a growth chamber under $28^{\circ} \mathrm{C}$, a $16 \mathrm{~h}$ light $\left(210 \mu \mathrm{mol} / \mathrm{m}^{2} \cdot \mathrm{s}\right)$ and $8 \mathrm{~h}$ dark photoperiod, and 75\% relative humidity for $10 \mathrm{~d}$. The leaf necrotic area was 
measured and the percentage of inhibition was calculated compared to the control [29]. The experiment was done three times with three replications for each treatment.

\subsection{Fruit Assay of Control Efficacy on B. cinerea}

The biocontrol potentials of XL17 and its CF against $B$. cinerea were tested with fruits. Matured, uniform, healthy green-fleshed kiwifruits (Actinidia chinensis var. deliciosa 'Hayward') were bought from a supermarket (Walmart, Hangzhou, China). All fruits were surface sterilized by immersing in $2 \%(v / v)$ sodium hypochlorite for 2 min and washing with sterile water and then were air-dried inside a clean bench [30]. A $3 \mathrm{~mm}$ deep $\times 3 \mathrm{~mm}$ wide wound was made using a sterile needle on one side of each kiwifruit. A drop $(20 \mu \mathrm{L})$ of XL17 culture $\left(1 \times 10^{8} \mathrm{CFU} \cdot \mathrm{mL}^{-1}\right)$, XL17 CF $(10 \%, 15 \%$, or $20 \%$ in sterile water), difenoconazole $\left(11.99 \mu \mathrm{g} \cdot \mathrm{mL}^{-1}\right)$ [31], or sterile water (control) was dropped to the wound and air-dried. A $5 \mathrm{~mm}$ mycelial plug of $B$. cinerea was attached on the wound site of each fruit. Then, the fruits were kept on a moistened filter paper in a sterile plastic box $(16 \mathrm{~cm} \times 10 \mathrm{~cm} \times 7 \mathrm{~cm})$. The boxes were sealed with parafilm and incubated at $28^{\circ} \mathrm{C}$ in the dark for $7 \mathrm{~d}$. A sterile PDA plug with sterile water was used as negative control and a mycelial plug of $B$. cinerea with sterile water was used as positive control. Lesion area was measured and the percentage of lesion inhibition was calculated compared to the control. The experiment was done three times with three replications for each treatment.

\subsection{Analysis of $16 S$ rRNA Gene Sequences}

The 16S rRNA gene sequence of strain XL17 was amplified from a colony by PCR using primers 27F (5'-AGAGTTTGATCCTGGCTCAG-3') and 1492R (5'-GGTTACCTTGTTACGACTT$\left.3^{\prime}\right)$ as previously described [29]. The amplicon was sequenced using the Sanger method and a $1411 \mathrm{bp}$ sequence was obtained and identified using the EzBioCloud identification service (https:/ / www.ezbiocloud.net/identify, accessed on 4 October 2021). The 16S rRNA gene sequences of strain XL17 and type strains of closely-related Pseudomonas species were aligned using the MUSCLE program integrated in the MEGA5 software [32]. After eliminating positions containing gaps and missing nucleotides at both ends of the aligned sequences, 1405 final aligned nucleotides were constructed to a phylogenetic tree using the maximum likelihood method based on the Tamura-Nei model and Gamma-distributed with invariant sites for evolutionary rates and patterns.

\subsection{Genome Sequencing and Assembly}

The genomic DNA of strain XL17 was extracted using the SDS method [33] and quantified by a Qubit ${ }^{\circledR} 2.0$ Fluorometer (Thermo Scientific, Waltham, MA, USA). A $350 \mathrm{bp}$ insert library was generated from $1 \mu \mathrm{g}$ of DNA using a NEBNext ${ }^{\circledR}$ Ultra $^{\mathrm{TM}}$ DNA Library Prep Kit (New England BioLabs, Ipswich, MA, USA) and sequenced using an Illumina NovaSeq PE150 platform at the Beijing Novogene Bioinformatics Technology Co., Ltd. (Beijing, China). Low-quality reads in raw data containing low-quality bases (mass value $\leq 20$ ) over $40 \%$, N over $10 \%$, or overlap with adapter sequences (length $\geq 15 \mathrm{bp}$, mismatch $\leq 3 \mathrm{bp}$ ) were removed by quality control using Readfq version 10 . All good-quality paired-end reads $(1277 \mathrm{Mb})$ of about 180 -fold coverage were assembled using SOAPdenovo version 2.04 [34], SPAdes version 3.11.1 [35], and ABySS version 2.0.2 [36]. The assembly results were integrated using CISA version 4.0 [37] into the least 26 scaffolds with an N50 length of 771,204 bp. The resultinh draft genome contains $6,841,285 \mathrm{bp}$ and has a $\mathrm{G}+\mathrm{C}$ content of $60.84 \%$. The draft genome sequence has been deposited at DDBJ/EMBL/GenBank under the accession no. JAJQKS000000000 and is annotated by the NCBI Prokaryotic Genome Annotation Pipeline [38].

\subsection{Genome Relatedness Analysis}

The digital DNA-DNA Hybridization ( $\mathrm{dDDH})$ value between pair genomes among strain XL17, strains showing the phylogeny of the 16S rRNA gene identical to strain XL17, and representative strains of species-level genomospecies within the P. corrugata subgroup 
was calculated using the Genome-to-Genome Distance Calculator (http:/ /ggdc.dsmz.de/ distcalc2.php, accessed on 6 October 2021) with Formula 2; a dDDH value of 70\% was used as the threshold for species delimitation [39].

\subsection{Genomic Analyses}

The draft genome sequence of strain XL17 was annotated and amino acid sequences were predicted using the online platform RAST (Rapid Annotation using Subsystem Technology) version 2.0 (http:/ / rast.nmpdr.org/, accessed on 8 October 2021). Gene clusters for the biosynthesis of secondary metabolites were found using the antiSMASH 6.0 pipeline with relaxed detection strictness (https: / / antismash.secondarymetabolites.org/, accessed on 10 October 2021) [40].

\subsection{Phylogenomic Analysis of the Pseudomonas Corrugata Subgroup}

Whole genome sequences (WGSs) of strain XL17, strains showing the phylogeny of the $16 S$ rRNA gene identical to strain XL17, and representative strains of species-level genomospecies within the P. corrugata subgroup were selected for phylogenomic analyses (Table S1). These WGSs were annotated using RAST for pan-genome analysis. The phylogenomic tree was constructed for the P. corrugata subgroup based on the proteins encoded by their core genomes. P. aeruginosa DSM 50071 ${ }^{\mathrm{T}}$ was selected as the outgroup. Orthologous clusters of proteins were analyzed and output by running the pan-genomes analysis pipeline [41]. Core proteins were determined by a BLAST E-value $<1 \mathrm{e}^{-10}$, sequence identity $>50 \%$, aligned sequence length coverage $>50 \%$, and score $>40$. The amino acid sequences from 1663 concatenated core proteins were concatenated and aligned using MAFFT version 5 [42]. The poorly aligned positions and excessively divergent regions were trimmed using GBlock 0.91b [43]. The resulting 509,085 amino acids were used to generate a maximum likelihood tree with the JTT + F + I + G4 model using the IQ-TREE version 2.1.2 [44]. The phylogenomic tree was displayed using the online tool iTOL version 5 [45].

\subsection{Determination of 2,4-Diacetylphloroglucinol (DAPG) Produced from XL17}

The presence of the phl operon (phlABCD) for biosynthesis of the phenolic polyketide DAPG was detected by PCR amplification of phlD partial sequences (about $745 \mathrm{bp}$ ) with the primers Phl2a (5'-GAGGACGTCGAAGACCACCA-3') and Phl2b (5'-ACCGCAGCAT CGTGTATGAG-3') [46]. PCR was performed with the $2 \times$ TSINGKE Master Mix (TsingKe Biological Technology, Beijing, China) and pre-denaturation at $94{ }^{\circ} \mathrm{C}$ for $3 \mathrm{~min}, 30$ cycles at $94{ }^{\circ} \mathrm{C}$ for $1 \mathrm{~min}, 62{ }^{\circ} \mathrm{C}$ for $1 \mathrm{~min}$, and $72{ }^{\circ} \mathrm{C}$ for $1 \mathrm{~min}$, with the final extension at $72{ }^{\circ} \mathrm{C}$ for $3 \mathrm{~min}$. The amplicon was sequenced using the Sanger method and identified by BLAST search in the NCBI database and submitted in GenBank under the accession no. MW851288. Phylogenetic analysis on the complete phlD sequences (1050 positions) from the WGS of strain XL17 and reference strains within the P. corrugata subgroup was performed using the MEGA5 software [32] with the maximum likelihood method based on the Tamura-Nei model and Gamma-distributed for evolutionary rates and patterns.

To identify DAPG produced by strain XL17, organic compounds were extracted from XL17 CF. Strain XL17 was cultured at $30^{\circ} \mathrm{C}$ and $200 \mathrm{rpm}$ for $48 \mathrm{~h} ; 40 \mathrm{~mL}$ of the culture was acidified with $440 \mu \mathrm{L}$ of $10 \%$ trifluoroacetic acid (TFA) to $\mathrm{pH} 2.0$, and then was extracted twice with $100 \mathrm{~mL}$ of ethyl acetate. The extracted solution was evaporated with a rotary evaporator. The resulting dry extract was suspended in $5 \mathrm{~mL}$ of $35 \%$ acetonitrile with $0.1 \%$ TFA and then filtered through a $0.22 \mu \mathrm{m}$ filter. Organic compounds were detected using an Agilent 1290 UHPLC system (Agilent Technologies, Santa Clara, CA, USA). An HPLC diode array detector was programmed to record absorbance at 270 and $310 \mathrm{~nm}$. Standard DAPG solution $\left(10 \mu \mathrm{g} \cdot \mathrm{mL}^{-1}\right)$ was prepared with $35 \%$ acetonitrile and $0.1 \%$ TFA. 


\subsection{Detection of Lipopeptides Produced from XL17 Cells}

Lipopeptides produced by a colony of strain XL17 were detected by matrix-assisted laser desorption ionization-time of flight mass spectrometry (MALDI-TOF-MS) as previously described [24].

\subsection{Detection of Fluorescent Pyoverdine Siderophore}

Fluorescent pyoverdine siderophore produced from XL17 colonies grown on King's B medium was detected under UV light [47]. Strain XL17 was grown in LB broth at $30^{\circ} \mathrm{C}$ for $48 \mathrm{~h}$. The culture was washed with sterile water and diluted to $1 \times 10^{8} \mathrm{CFU} \cdot \mathrm{mL}^{-1}$ and $5 \mu \mathrm{L}$ of the diluted culture was dropped at the center of a King's B agar plate. The culture was further diluted to $1 \times 10^{4} \mathrm{CFU} \cdot \mathrm{mL}^{-1}$ and $50 \mu \mathrm{L}$ of the diluted culture was spread on a King's B agar plate. The plates were incubated at $30^{\circ} \mathrm{C}$ for $48 \mathrm{~h}$ and were observed under UV light.

\subsection{Detection of Hydrolytic Enzyme Activities}

Enzyme activities of hydrolytic chitinases, $\beta$-1,3-glucanases, and proteases from strain XL17 was tested as previously described [24]. Paenibacillus peoriae CGMCC $1.3761^{\mathrm{T}}$, which showed clear hydrolytic zones [24], was used as positive control.

\subsection{Assay of Indole Acetic Acid (IAA) Production}

IAA production by strain XL17 was determined using the colorimetric assay developed by Sarwar and Kremer [48] as previously described [24].

\subsection{Detection of 1-Aminocyclopropane-1-Carboxylate Deaminase Activity}

XL17 colonies grown on LB agar were streaked on solid nitrogen-free DF medium [49], DF medium with $3 \mathrm{mM}$ 1-aminocyclopropane-1-carboxylic acid (ACC) as the sole nitrogen source, or DF medium with $1.5 \mathrm{mM}\left(\mathrm{NH}_{4}\right)_{2} \mathrm{SO}_{4}$ as the sole nitrogen source, and allowed to grow for $2 \mathrm{~d}$. Bacteria producing ACC deaminase can grow on the DF medium with ACC as the sole nitrogen source.

\subsection{Assays of Toxic or Beneficial Potentials of Strain XL17 on Plants}

Rice (Oryzae sativa) is one of the test crops for phytotoxicity assay recommended by the Organization for Economic Cooperation and Development [50]. Rice seeds (cv. II you 023) were surface sterilized by $3 \%$ sodium hypochlorite solution for $10 \mathrm{~min}$ and washed six times with sterile water. Rice seeds were soaked in sterile water overnight and then each seed in $1 \mathrm{~mL}$ of sterile water (control), XL17 culture, XL17 CF (10, 15 and 20\%), streptomycin sulphate $\left(65 \mu \mathrm{g} \cdot \mathrm{mL}^{-1}\right)$, or difenoconazole $\left(11.99 \mu \mathrm{g} \cdot \mathrm{mL}^{-1}\right)$ for $4 \mathrm{~h}$. Seeds $(n=20)$ were placed on a moistened sterile filter paper in a $15 \mathrm{~mm}$ Petri dish. The Petri dishes were kept in a growth chamber under $26^{\circ} \mathrm{C}$, a $16 \mathrm{~h}$ light and $8 \mathrm{~h}$ dark photoperiod, and $80 \%$ relative humidity for $7 \mathrm{~d}$. The germination percentage, root length, shoot height, and dry weight of the rice seedlings were recorded. The experiments were done with three replicates.

To determine epiphytic root colonization by strain XL17, at $7 \mathrm{~d}$ after inoculation, bacteria adhering to roots were washed into $3 \mathrm{~mL}$ of sterile water and serially diluted; $100 \mu \mathrm{L}$ of the bacterial suspensions were spread on LB agar. To determine endophytic colonization by strain XL17 in roots and stems, roots and stems were surface-sterilized by $70 \%$ ethanol for $1 \mathrm{~min}$ and 1\% sodium hypochlorite for $2 \mathrm{~min}$, and washed with sterile water six times. The sterilization efficacy was determined by no bacterial growth from the last-washed water. The surface-sterilized roots and stems were ground in sterile water. The homogenate suspensions were serially diluted; $100 \mu \mathrm{L}$ of the diluted suspensions were spread on LB agar. After incubating the LB agar plates at $30^{\circ} \mathrm{C}$ for $3 \mathrm{~d}$, bacterial colonies showing the colony morphology of strain XL17 were counted. The experiments were done with three replicates. 


\subsection{Statistical Analysis}

The SPSS 16.0 software (SPSS Inc. South Wacker Drive, Chicago, IL, USA) was used for statistical analysis of variance followed by post hoc multiple comparisons. The least significance difference test was performed to separate values of different treatments at $p<0.05$. The values were the mean \pm standard error of at least three replicates for each treatment.

\section{Results}

\subsection{Strain XL17 Showed High Antimicrobial Activities against B. cinerea and Psa}

Strain XL17 inhibited radial growth of $B$. cinerea grown on PDA for $7 \mathrm{~d}$ up to $35 \mathrm{~mm}$ (Figure 1A) and inhibited growth of Psa grown in LB agar for $3 \mathrm{~d}$ to a clear zone of $15 \mathrm{~mm}$ diameter (Figure 1B).
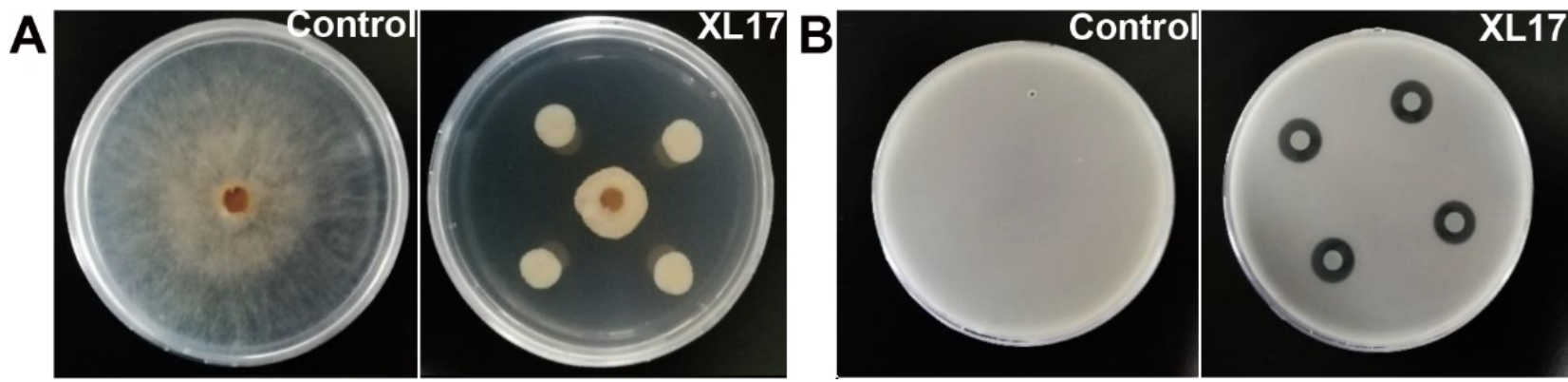

Figure 1. XL17 inhibits growth of gray mold Botrytis cinerea grown on potato dextrose agar for $7 \mathrm{~d}$ (A) and bacterial canker pathogen Pseudomonas syringae pv. actinidiae grown in LB agar for $3 \mathrm{~d}$ (B).

After 7 d growth in PDB containing 10\%, 15\%, or 20\% CF of strain XL17, the dry weight of B. cinerea mycelia was $7.4 \%, 4.5 \%$, and $2.1 \%$ of that in $\mathrm{PDB}$ without $\mathrm{CF}$, respectively (Figure $2 \mathrm{~A}, \mathrm{~B}$ ).
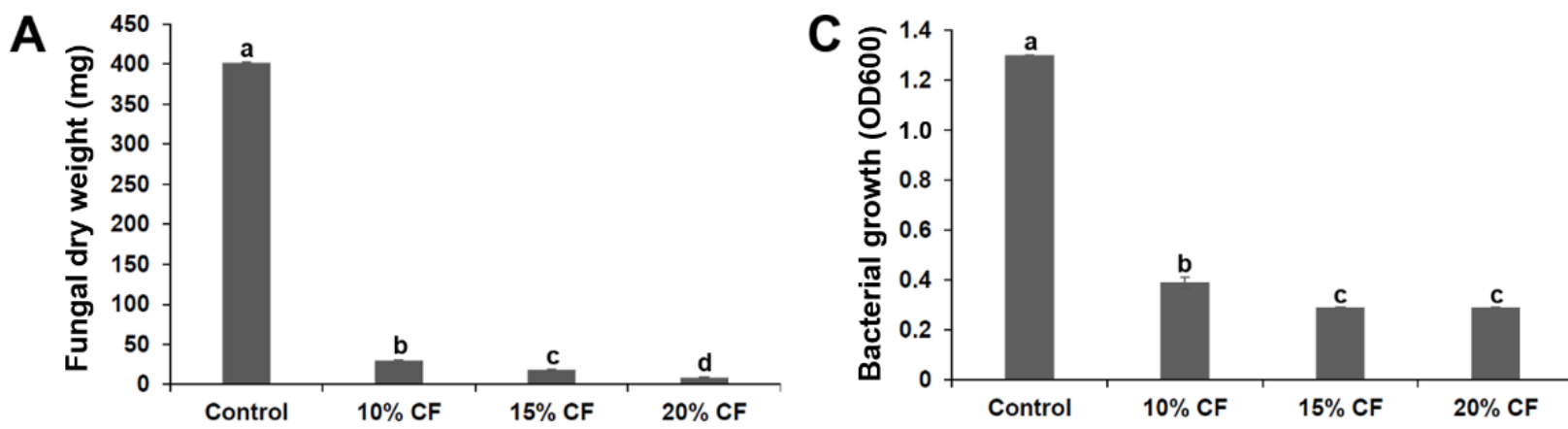

B
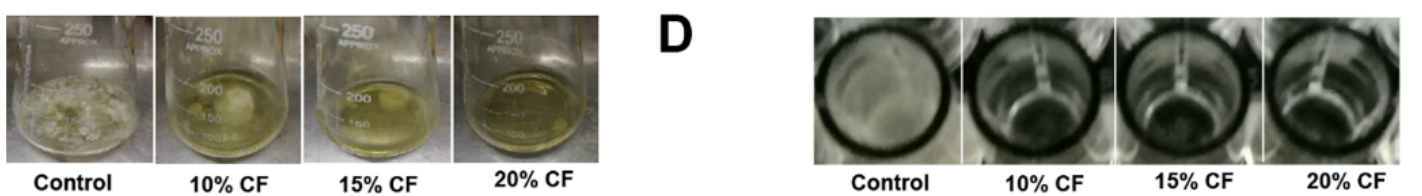

Figure 2. Culture filtrate (CF) of strain XL17 inhibits growth of Botrytis cinerea in potato dextrose broth $(\mathbf{A}, \mathbf{B})$ and Pseudomonas syringae pv. actinidiae in LB broth $(\mathbf{C}, \mathbf{D})$. Bacterial growth is indicated by optical density at $600 \mathrm{~nm}$ (OD600). The values are mean \pm standard error of three replicates for each treatment. Different letters show significant difference at $p<0.05$.

After $24 \mathrm{~h}$ growth in LB containing 10\%, 15\%, or 20\% CF of strain XL17 in microplate wells, the OD600 of Psa was 30\%, 22\%, and 22\% of that in LB without CF, respectively (Figure 2C,D).

\subsection{XL17 CF Damaged Psa Cells and B. cinerea Hyphae}

SEM and TEM revealed cell damage of Psa and B. cinerea grown with XL17 CF. In contrast to the intact cell envelopes and condensed cell contents of control cells (Figure 3A,E), 
Psa grown with CF was broken and lost cell contents (Figure 3B,F). Likewise, control $B$. cinerea hyphae with smooth and intact cell walls contained electron-dense cell organelles and contents (Figure 3C,G), whereas hyphae grown with $\mathrm{CF}$ were broken and fragmented and lost cell contents (Figure 3D,H). XL17 CF contains antimicrobial agents which can breach the cell envelopes of the bacterial and fungal pathogens.
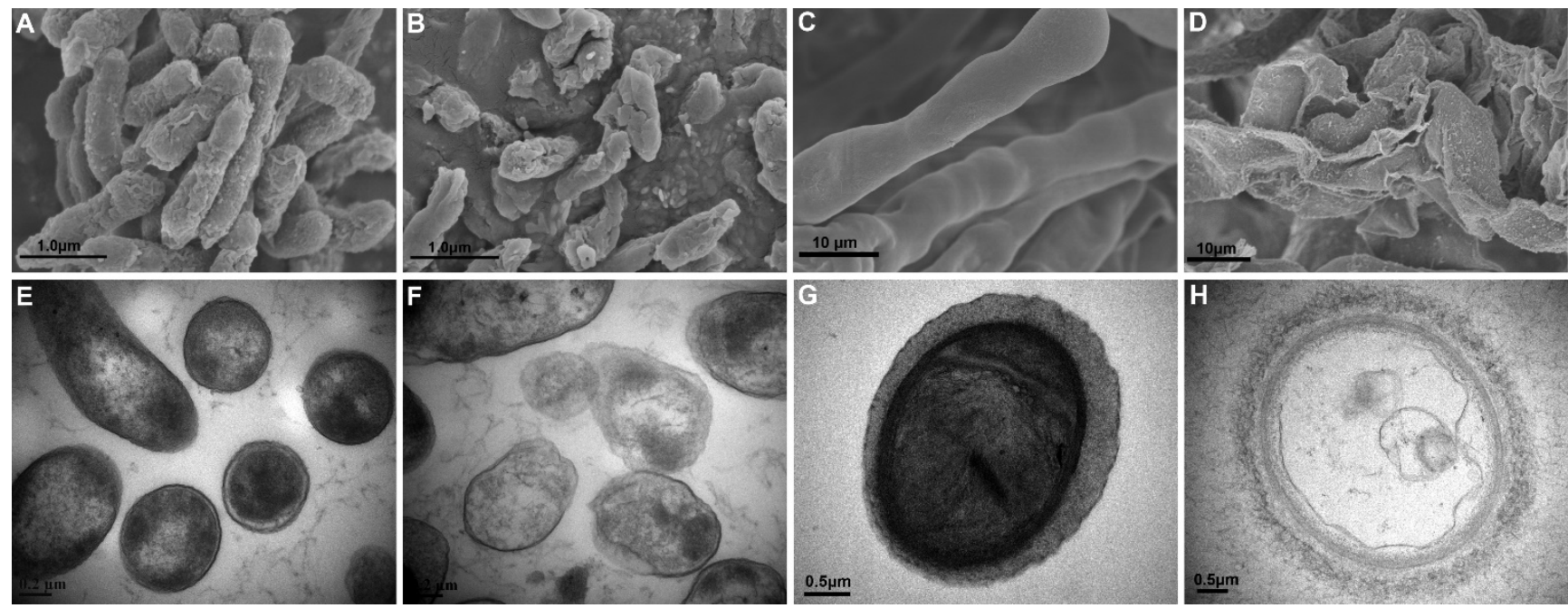

Figure 3. Structures of Pseudomonas syringae pv. actinidiae (Psa) cells and Botrytis cinerea hyphae shown by scanning electron microscopy (A-D) and transmission electron microscopy (E-H). Control Psa cells are intact $(\mathbf{A}, \mathbf{E})$ with electron-dense cell contents (E), whereas Psa cells grown with $20 \%$ culture filtrate of strain XL17 are broken and shrunken (B) and lost cell contents (F). Control hyphae with smooth and intact cells walls $(\mathbf{C}, \mathbf{G})$ contain electron-dense cell organelles and contents $(\mathbf{G})$, whereas hyphae grown with $20 \%$ culture filtrate of strain XL17 are broken and fragmented (D) and lost cell contents $(\mathbf{H})$.

\subsection{Strain XL17 and XL17 CF Reduced Leaf Necrosis Caused by Psa and Gray Mold Lesions in Kiwifruits}

Psa caused necrosis in leaves after wounding inoculation. Streptomycin, XL17, and XL17 CF inhibited the necrosis. Streptomycin reduced $94 \%$ of the necrosis area while XL17 and $20 \%$ CF reduced $92 \%$ of the necrosis area after $10 \mathrm{~d}$ of the wounding inoculation (Figure $4 \mathrm{~A}, \mathrm{~B}$ ).

B. cinerea caused gray mold lesions in kiwifruits after wounding inoculation. Difenoconazole, XL17, and XL17 CF inhibited the lesions. Difenoconazole reduced $82 \%$ of the lesion area while $\mathrm{XL17}, 20 \% \mathrm{CF}, 15 \% \mathrm{CF}$, and $10 \% \mathrm{CF}$ reduced $95.5 \%, 94.6 \%, 93.0 \%$, and $92.2 \%$, respectively, of the lesion area after $7 \mathrm{~d}$ of the wounding inoculation (Figure $4 \mathrm{C}, \mathrm{D}$ ).

\subsection{Strain XL17 Belongs to Pseudomonas bijieensis within the Pseudomonas corrugata Subgroup}

The 16S rRNA gene sequence of strain XL17 was amplified and a $1411 \mathrm{bp}$ sequence was obtained. Blast search of the $1411 \mathrm{bp}$ sequence showed that it is identical to the $16 \mathrm{~S}$ rRNA gene sequences of P. fluorescens strains DR133, Pf275, and FW300-N2C3 and Pseudomonas sp. strain St290, one nucleotide different from that of $P$. fluorescens strain 2P24, and two nucleotides different from that of $P$. bijieensis type strain L22-9 ${ }^{\mathrm{T}}$. The phylogenetic tree constructed based on 1405 aligned positions of the $16 \mathrm{~S}$ rRNA gene sequences showed identical phylogeny of strains XL17, DR133, Pf275, St290, L22-9 ${ }^{\mathrm{T}}$, 2P24, and FW300-N2C3 neighboring to P. corrugata (Figure 5). Based on 16S rRNA gene sequences, strain XL17 cannot be classified to a species but was classified to the P. corrugata subgroup.

To clarify the taxonomy status of strain XL17, we used the Illumina platform to sequence the WGS of strain XL17 and obtained a draft genome (accession no. JAJQKS000000000). Genome relatedness analysis showed that strains XL17, DR133, Pf275, St290, and 43MFCvi1.1 and P. bijieensis $\mathrm{L} 22-9^{\mathrm{T}}$ share $\mathrm{dDDH}$ similarities higher than $90 \%$ (Table S1) and thus belong to $P$. bijieensis. Strain $2 \mathrm{P} 24$ shares the highest $\mathrm{dDDH}$ similarities (about $62 \%$ ) to P. bijieensis 
among all the genomes released in the NCBI genome database and thus represents a novel genomospecies most close to P. bijieensis. Strains FW300-N2C3, MPBD7-1, FW305-28, and PDM06 share dDDH similarities higher than $80 \%$ and belong to a same species; they share dDDH similarities lower than $70 \%$ to other genomes (Table S1) and thus represent a novel genomospecies. P. bijieensis is the species-level cluster (genomospecies) 18 of the $P$. corrugata subgroup within the $P$. fluorescens species complex while strain 2P24 represents genomospecies 17 and strain FW300-N2C3 represents genomospecies 22 [2] (Table S1).

A
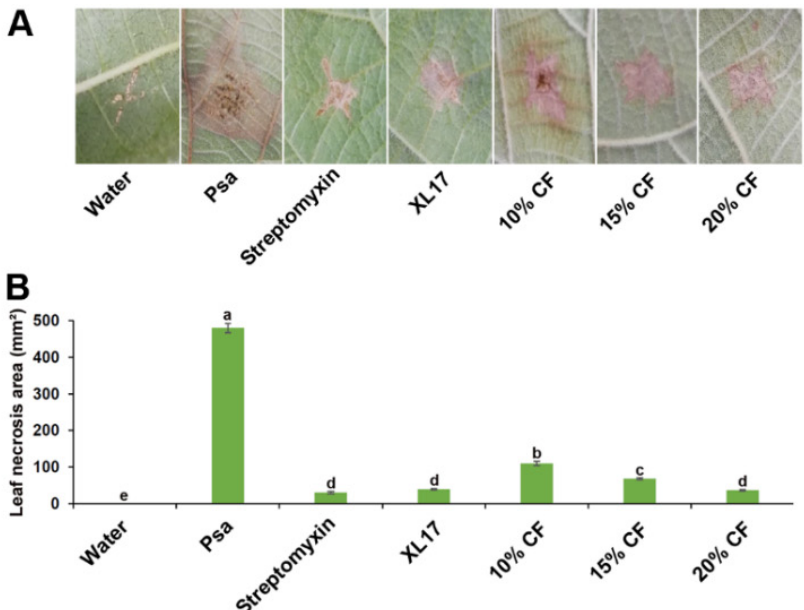

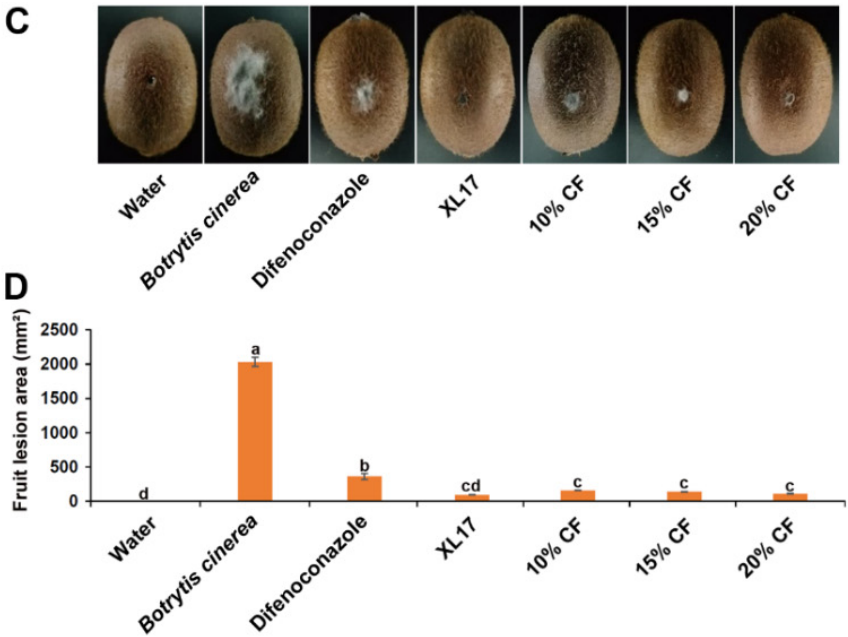

Figure 4. Strain XL17 and culture filtrate (CF) of strain XL17 inhibit necrosis in kiwifruit leaves caused by Pseudomonas syringae pv. actinidiae (Psa) after $10 \mathrm{~d}$ of wound inoculation (A,B) and lesions in kiwifruits caused by Botrytis cinerea after $7 \mathrm{~d}$ of wound inoculation $(\mathbf{C}, \mathbf{D})$. Leaf necrosis $(\mathbf{A})$ caused by Psa under various treatments. Fruit lesions (C) caused by B. cinerea under various treatments. Leaf necrosis areas (B) and fruit lesion areas (D) are mean \pm standard error of three replicates for each treatment. Different letters show significant difference at $p<0.05$.

\subsection{Phylogeny and Genetic Markers Associated with Plant-Interaction Life Styles in the Pseudomonas corrugata Subgroup}

Phylogenomic analysis based on 1663 core proteins sharing the P. corrugata subgroup and the outgroup P. aeruginosa DSM $50071^{\mathrm{T}}$ showed that the P. corrugata subgroup contains two major monophyletic clades. Clade 1 contained Pseudomonas genomospecies 1 to 7 including P. corrugata (Pseudomonas genomospecies 5) and P. mediterranea (Pseudomonas genomospecies 1) [2]. All genomospecies within Clade 1 contain the lipopeptide/quorum sensing (LPQ) genomic island, which serves as a genetic marker for the plant-pathogenic life style of the P. corrugata subgroup [51], but not the phl operon (phlACBD) for DAPG biosynthesis, the gene cluster encoding a type III secretion system (T3SS) similar to the Hrp1 T3SS important for P. syringae virulence, and the single "orphaned" T3SS effector gene similar to the P. syringae hopAA gene (Figure 6). Clade 2 contained Pseudomonas genomospecies 8 to 29 [2], "P. marvdashtae" and "P. zanjanensis" [1] (Figure 6). Among the 24 genomospecies within the Clade 2, 10 genomospecies contain the LPQ island while 11 genomospecies contain the phl operon; only genomospecies 25 and 28 contain both the phl operon and LPQ island, while the 9 genomospecies containing the phl operon but no LPQ island contain the Hrp1 T3SS (Figure 6). The presence of hopAA is not congruent with the presence of the $p h l$ operon. Among the 11 genomospecies containing the $p h l$ operon, five genomospecies ( $P$. thivervalensis, genomospecies $8,17,25$, and 28 ) do not contain the hop $A A$ gene (Figure 6). On the other hand, genomospecies containing the hop $A A$ gene may not contain the phl operon, such as "P. alvandae", genomospecies 10 and 23.

The phylogeny of the phlD gene encoding the type III polyketide synthase (Figure 7) was congruent with the species phylogeny (Figure 6). Notably, the genomospecies 26 was designated as "Pseudomonas ogarae" with the type strain F113 ${ }^{\mathrm{T}}$ by Garrido-Sanz et al. [2] and later as "Pseudomonas zarinae" with the type strain SWRI108 ${ }^{\mathrm{T}}$ by Girard et al. [1]. The 
members of P. ogarae formed two phylogroups [2] represented by strain $\mathrm{F} 113^{\mathrm{T}}$ and strain SWRI108 ${ }^{\mathrm{T}}$ (Figure 6); the two phylogroups share dDDH similarities of 73.0-75.6\% (Table S2) below the DDH threshold of 79-80\% for subspecies delimitation [52] and can be differentiated by the presence ( $p h l+)$ and absence ( $p h l-)$ of the phl operon (Figure 6; Table S2), and thus can be divided into two subspecies named as Pseudomonas ogarae subsp. ogarae (phl+) and Pseudomonas ogarae subsp. zarinae (phl-).

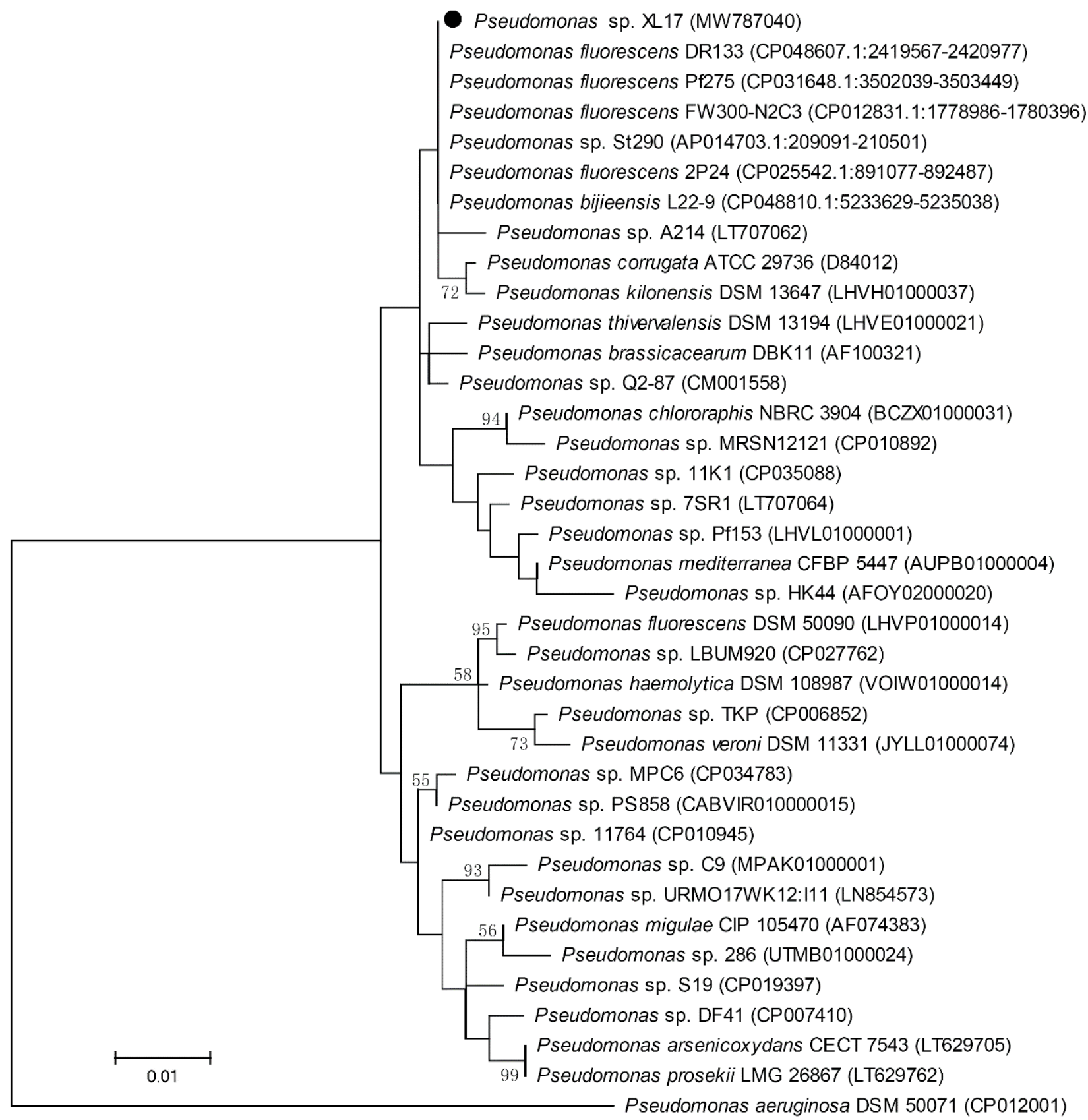

Figure 5. Maximum likelihood phylogenetic tree based on 16S rRNA gene sequences (1405 positions) of strain XL17 $(\bullet)$ and related Pseudomonas strains. Pseudomonas aeruginosa DSM $50071^{\mathrm{T}}$ was used as outgroup. The percentages of replicate trees $(>50 \%)$ in which the associated taxa clustered together in the bootstrap test (1000 replicates) are shown at the nodes. The GenBank accession numbers of the $16 \mathrm{~S}$ rRNA gene sequences are indicated in brackets. The scale bar indicates 0.01 substitutions per site. 


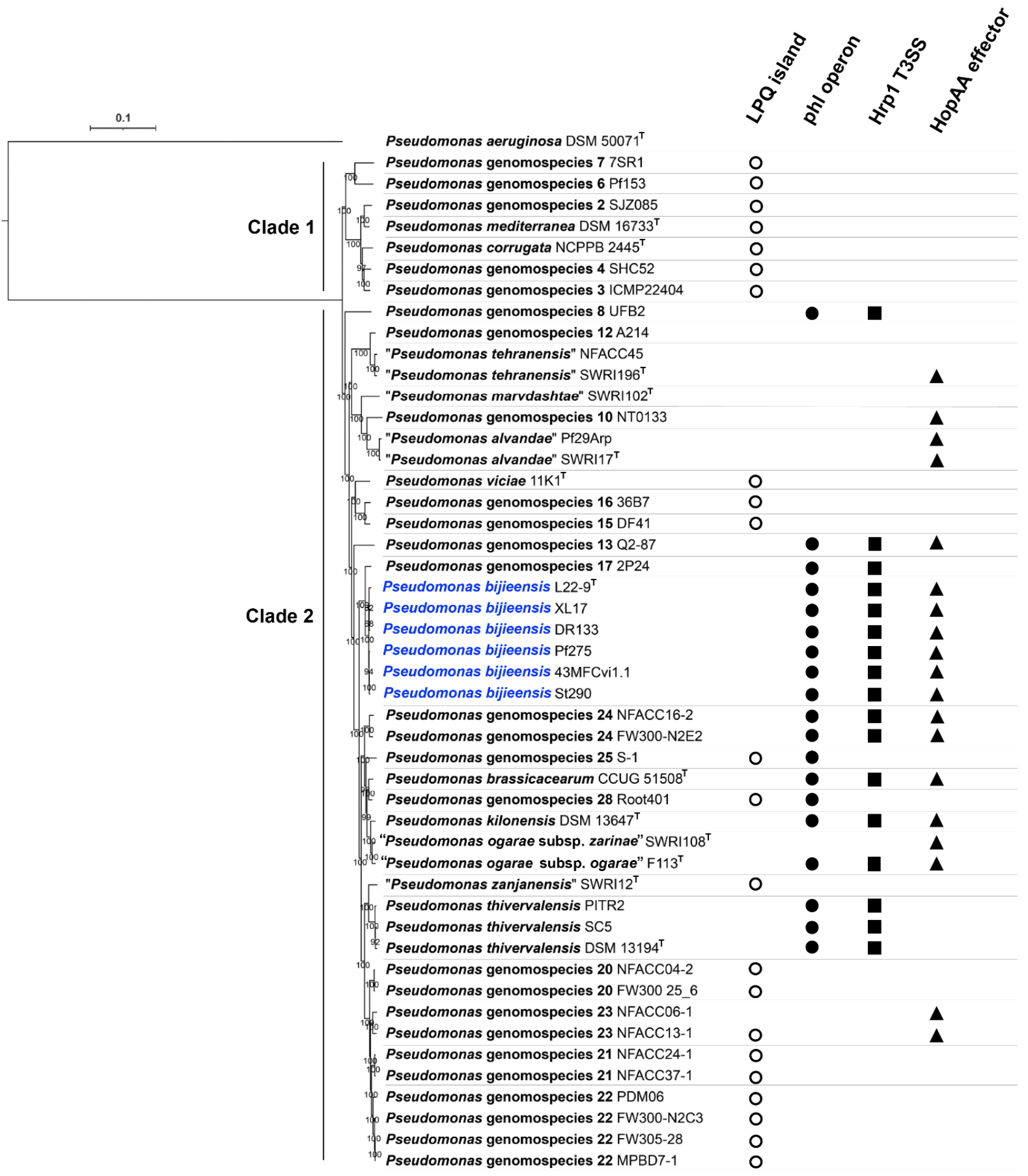

Figure 6. Phylogenomic tree based on concatenated 509,085 amino acid sequences of 1663 core proteins from strains within the Pseudomonas corrugata subgroup and the outgroup strain P. aeruginosa DSM 50071 ${ }^{\mathrm{T}}$. The maximum likelihood tree was generated using IQ-TREE 2.1.2 program with JTT + F + I + G4 model. Bootstrap values of 1000 tests are shown at the nodes. The scale bar indicates 0.1 substitutions per site. The P. corrugata subgroup consists of two monophyletic clades (Clade 1 and Clade 2). Pseudomonas bijieensis is highlighted in blue. Distribution of genetic markers LPQ island $(\bigcirc)$, phl operon $(\bullet)$, Hrp1 T3SS $(\boldsymbol{\square})$, and HopAA effector $(\boldsymbol{\Delta})$ associated with plant-interaction life styles are labelled after the strain holding the genetic markers. 


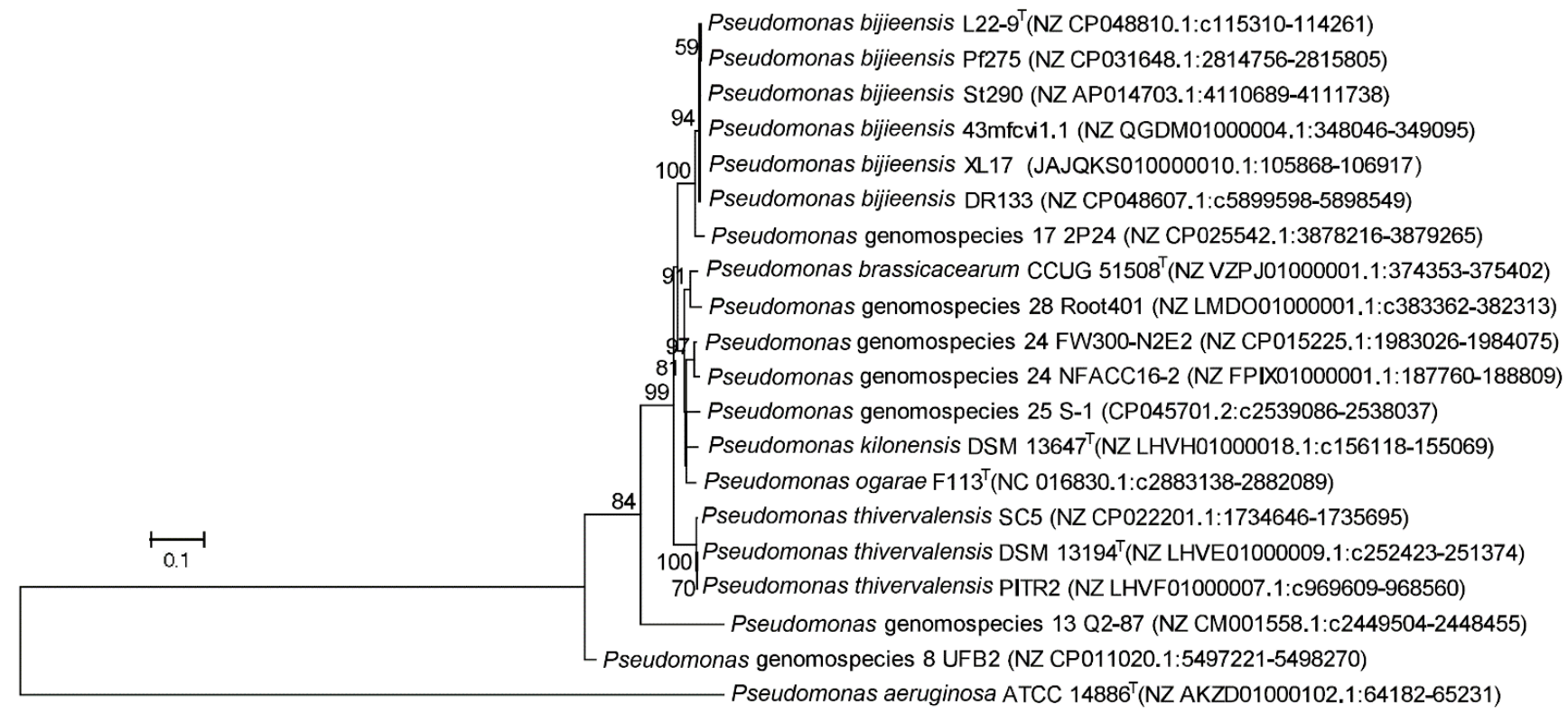

Figure 7. Maximum likelihood phylogenetic tree based on complete phlD gene sequences (1050 positions) encoding type III polyketide synthase of strains within the Pseudomonas corrugata subgroup. P. aeruginosa ATCC $14886^{\mathrm{T}}$ was used as outgroup. The percentages of replicate trees $(>50 \%)$ in which the associated taxa clustered together in the bootstrap test (1000 replicates) are shown at the nodes. The scale bar indicates 0.1 substitutions per site. The phlD gene sequences were extracted from whole genome sequences whose accession numbers in GenBank are indicated in brackets.

\subsection{Genes Associated with Plant-Interaction Life Style in Pseudomonas bijieensis and Strain 2P24}

Six strains belonging to P. bijieensis and strain 2P24-represented Pseudomonas genomospecies 17 formed a branch within Clade 2 (Figure 6). The antiSMASH 6.0 pipeline with relaxed detection strictness identified 15-18 regions for the biosynthesis of secondary metabolites from the WGSs of $P$. bijieensis strains and 14 gene clusters from the WGS of strain 2P24 (Figure S1). P. bijieensis strains share 15 biosynthetic gene clusters. P. bijieensis and strain 2P24 share 13 biosynthetic gene clusters and show their close relation.

$P$. bijieensis and strain 2P24 contain multiple gene clusters for the biosynthesis of antimicrobial agents. They contain the gene cluster for DAPG biosynthesis, having $100 \%$ similarity to the reference gene cluster from Pseudomonas genomospecies 13 strain Q287 (Figure S1). They contain the gene cluster for aryl polyene (APE Vf) biosynthesis, having $40 \%$ similarity to the reference gene cluster from Aliivibrio fischeri strain ES114 (Figure S1). They contain the gene cluster (Region 5.1 in strain XL17; Region 8 in strain 2P24) for the biosynthesis of a linear lipopeptide (Val-Ala-Gln-Ala-Val-Ala-Pro-Thr), having $8 \%$ similarity to the reference gene cluster for the biosynthesis of the cyclic lipotetradecapeptide entolysin from P. entomophila strain L48 and 17\% (P. bijieensis) or 23\% (strain 2P24) similarity to the reference gene cluster for the cyclic lipopeptide syringomycin from P. syringae strain B728a (Figure S1). This lipopeptide cluster encodes non-ribosomal peptide synthetase (NRPS)/polyketide synthase (PKS) (accession no. WP_232200821 and WP_232200822) similar to the cyclic lipopeptide syringopeptin NRPS (accession no. WP_161421051, identity about 48\%), massetolide NRPS (accession no. ABH06368.2, identity about 42\%), and orfamide NRPS (accession no. AAY91420, identity about 43\%). These three gene clusters for the biosynthesis of DAPG, aryl polyene, and the linear lipopeptide have been identified for contribution to the biocontrol activity of P. bijieensis Pf275 [47].

$P$. bijieensis and strain 2P24 contain two or three NRPS gene clusters related to the biosynthesis of fluorescent siderophore pyoverdine (Figure S1). Pyoverdine biosynthetic gene clusters are present in all genomospecies within Clade 2 and the genomospecies 6 and 7 within Clade 1 as previously shown (Supplementary File S7 in Garrido-Sanz et al. [2]). In P. bijieensis WGS, one pyoverdine biosynthetic gene cluster (Region 11 in strain Pf275; 
Region 20.1 connecting with Region 1.1 in strain XL17) (Figure S1) including pvdD encoding a NRPS/PKS (Pf275 PvdD accession no. WP_116833073; XL17 PvdD accession no. WP_232201727) has been identified for its contribution to the biocontrol activity of P. bijieensis Pf275 [47].

P. bijieensis and strain 2P24 contain two other NRPS gene clusters related to metallophore biosynthesis. One (Region 17.1 in strain XL17; Region 1 in strain 2P24) has a $37 \%$ similarity to the reference gene cluster for the biosynthesis of the metallophore fragin from Burkholderia cenocepacia strain H111 (Figure S1). The other (Region 5.3 connecting with Region 10.1 in strain XL17, Region 9 in strain Pf275, and Region 10 in strain 2P24) has a $7 \%$ similarity to the reference gene cluster for the biosynthesis of the siderophore crochelin A from Azotobacter chroococcum strain NCIMB 8003 (Figure S1); the NRPS/PKS (accession no. WP_116832671 in Pf275) encoded by this gene cluster shows identities about $32-35 \%$ to those for the biosynthesis of the linear lipopeptide (Val-Ala-Gln-Ala-Val-Ala-ProThr) and identities about 35-37\% to those for the biosynthesis of the cyclic lipopeptides syringopeptin, massetolide, and orfamide.

P. bijieensis and strain 2P24 contain a butyrolactone biosynthetic gene cluster (Region 5.2 in strain XL17; Region 9 in strain 2P24) (Figure S1) encoding polyketide synthase (accession no. WP_232200998 in strain XL17 and WP_134924657 in strain 2P24) and polyketide cyclase (accession no. WP_232200999 in strain XL17 and WP_134924658 in strain 2P24), which may be involved in the biosynthesis of cyclic polyketides.

P. bijieensis and strain 2P24 contain a beta-lactone biosynthetic gene cluster (Region 2.3 in strain XL17; Region 6 in strain 2P24) having 13\% similarity to the reference gene cluster for the biosynthesis of the antifungal lipopeptide fengycin from Bacillus velezensis strain FZB42 (Figure S1).

P. bijieensis and strain 2P24 do not contain the LPQ island carrying genes for the production of cyclic lipopeptide phytotoxins (syringopeptin and syringomycin) and the acyl-homoserine lactone quorum-sensing system, which is responsible for the pathogenicity of certain species within the $P$. corrugata subgroup [51,53].

P. bijieensis and strain $2 \mathrm{P} 24$ contain hcnBAC genes encoding hydrogen cyanide synthase (XL17 HcnA accession no. WP_162893903, HcnB accession no. WP_176688071, HcnC accession no. WP_116832142), which are present in all genomospecies within the P. corrugata subgroup as previously shown (Supplementary File S7 in Garrido-Sanz et al. [2]).

P. bijieensis and strain 2P24 contain two types (Hrp1 and SPI-1) of T3SS [2,54,55]. P. bijieensis but not strain 2P24 contains the single "orphaned" T3SS effector gene hopAA (Figure 6).

$P$. bijieensis and strain 2P24 contain genes encoding 1-aminocyclopropane-1-carboxylate (ACC) deaminase (accession no. WP_109753447), which is present in 20 genomospecies within the $P$. corrugata subgroup as previously shown (Supplementary File S7 in Garrido-Sanz et al. [2]).

\subsection{Strain XL17 Produced DAPG and Cyclic Lipopeptides of the Viscosin Family and Orfamide Family}

Organic compounds were extracted using ethyl acetate from acidified CF of strain XL17 at the stationary phase grown in LB broth and then determined by HPLC as well as the DAPG standard solution $\left(10 \mu \mathrm{g} \cdot \mathrm{mL}^{-1}\right)$. DAPG standard was detected at the retention time of 16.447 by the absorbance at $270 \mathrm{~nm}$ (Figure 8A). A component from the organic extract of XL17 CF showed an almost identical retention time (16.444) (Figure 8B) as the DAPG standard and thus was identified as DAPG.

From XL17 colonies, MALDI-TOF-MS detected cyclic lipopeptides of the viscosin family, including massetolides and viscosins with mass peaks ranging from 1110 to $1175 \mathrm{~m} / z$ [56-58], and the orfamide family, with mass peaks ranging from 1250 to $1330 \mathrm{~m} / z$ [59-61] (Figure 8C).

\subsection{Strain XL17 Produced Pyoverdine, $\beta-1,3-$ Glucanase, and Protease}

Strain XL17 produced and secreted fluorescent pyoverdine siderophore on the King's B medium (Figure 9A,B). Strain XL17 showed much weaker $\beta$-1, 3-glucanase activity 
and protease activity compared to Paenibacillus peoriae CGMCC 1.3761 and did not show chitinase activity (Figure 9C).
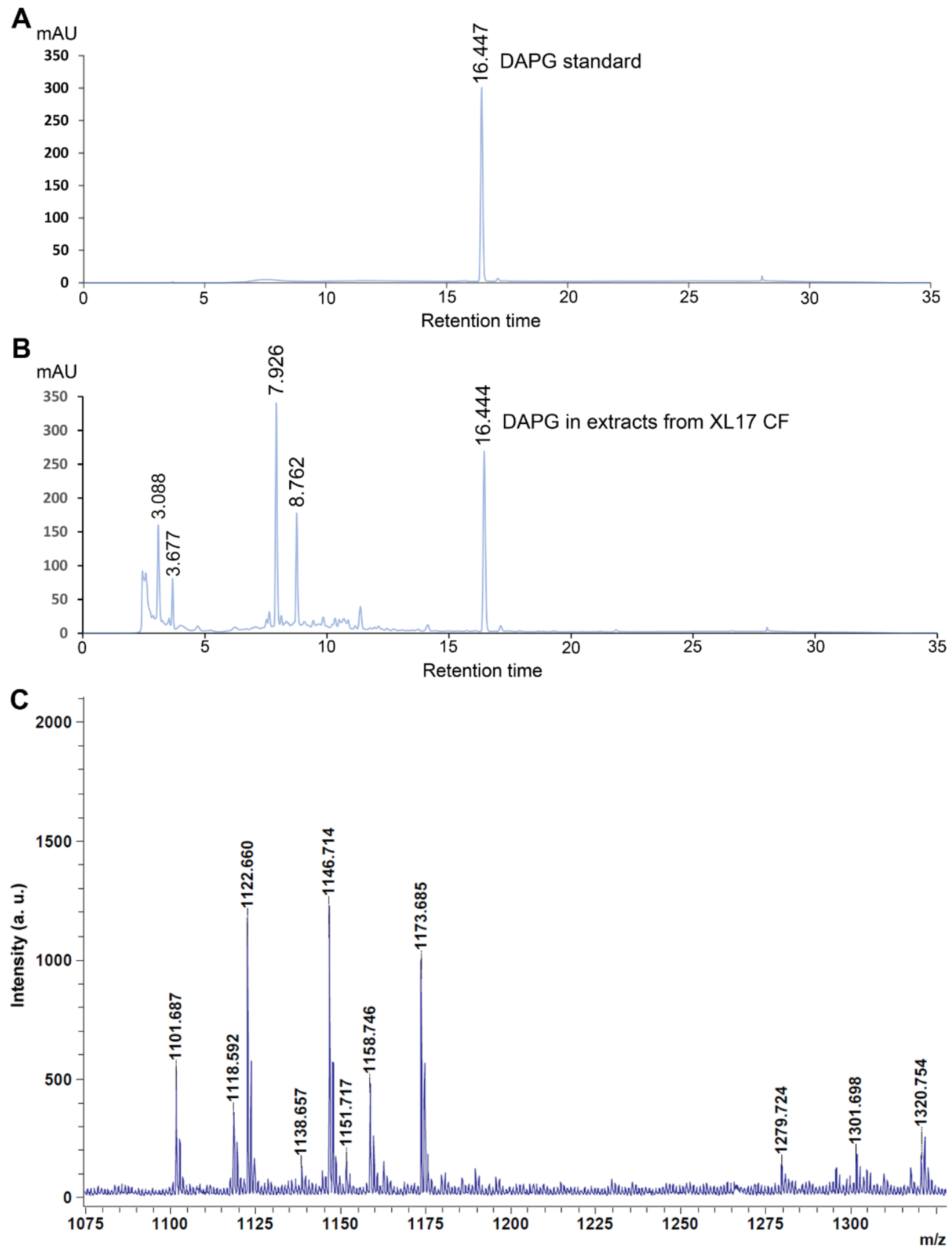

Figure 8. Strain XL17 produces polyketide 2,4-diacetylphloroglucinol (DAPG) and lipopeptides. (A) Standard DAPG $\left(10 \mu \mathrm{g} \cdot \mathrm{mL}^{-1}\right)$ detected by high-performance liquid chromatography (HPLC) has a retention time of 16.447. (B) DAPG detected from organic extracts of cell-free culture filtrate (CF) of strain XL17 grown in LB broth by the HPLC system has an almost identical retention time (16.444) as the standard DAPG. (C) Lipopeptides detected from a XL17 colony by MALDI-TOF-MS. Mass peaks ranging from 1110 to $1175 \mathrm{~m} / \mathrm{z}$ and from 1250 to $1330 \mathrm{~m} / \mathrm{z}$ indicate cyclic lipopeptides of viscosin family and orfamide family, respectively. 

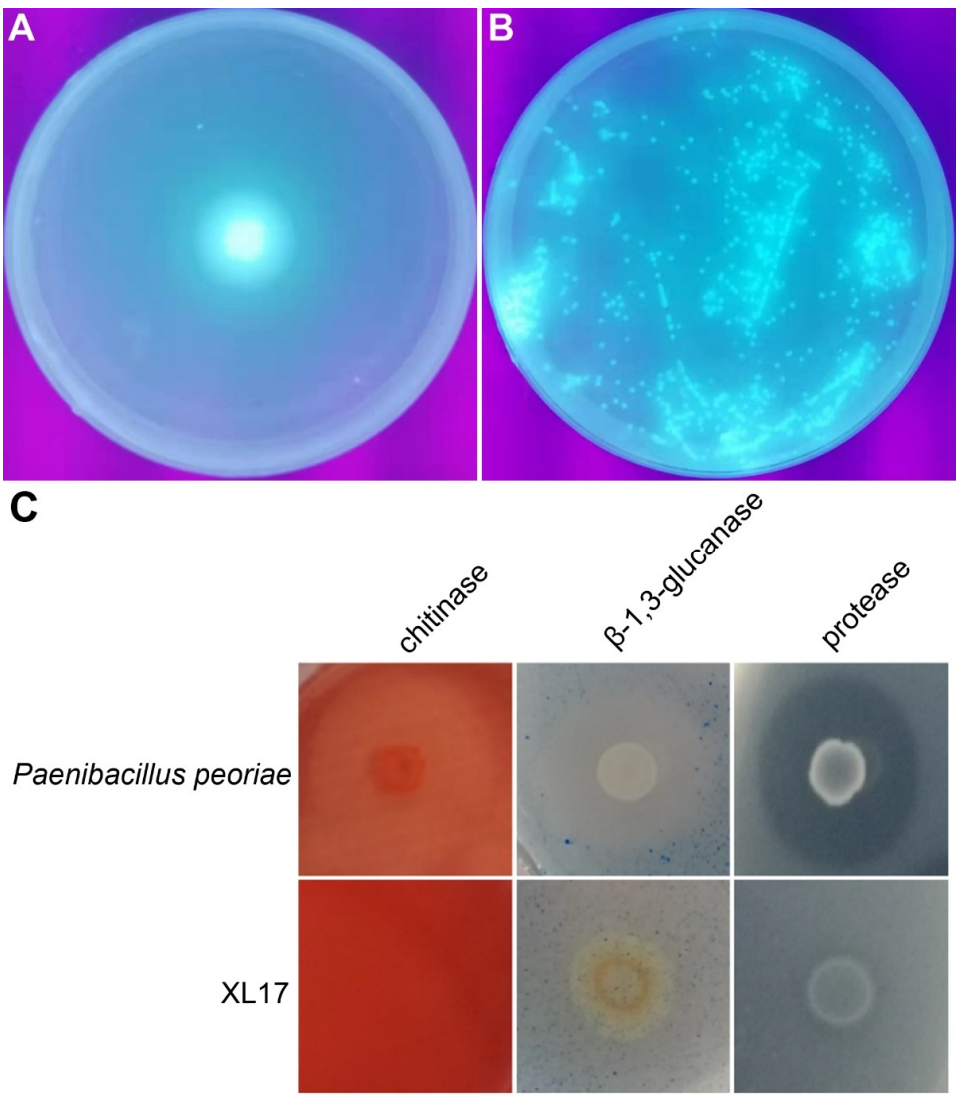

Figure 9. Agar plate assays show bacterial production of fluorescent pyoverdine siderophore and hydrolysis of chitin, $\beta$-1,3-glucan, and casein by bacterial chitinase, $\beta$-1,3-glucanase, and protease. (A) XL17 cells dropped at the center of the King's B agar plate grow and secrete fluorescent pyoverdine siderophore appearing under UV light. (B) XL17 cells spread on the Kings' B agar plate grow to colonies showing fluorescence. (C) Paenibacillus peoriae CGMCC $1.3761^{\mathrm{T}}$ used as positive control hydrolyses chitin, $\beta$-1,3-glucan, and casein while strain XL17 weakly hydrolyses $\beta$-1,3-glucan and casein.

\subsection{Strain XL17 Produced IAA and ACC Deaminase}

Strain XL17 produced about $37 \mu$ g of IAA from LB culture at $1 \times 10^{9} \mathrm{CFU} \mathrm{mL}^{-1}$. Strain XL17 did not grow on the nitrogen-free DF medium but grew well on the DF medium with ACC or ammonia as the sole nitrogen source (Figure 10). In congruence with the presence of the ACC deaminase gene, strain XL17 can produce ACC deaminase.
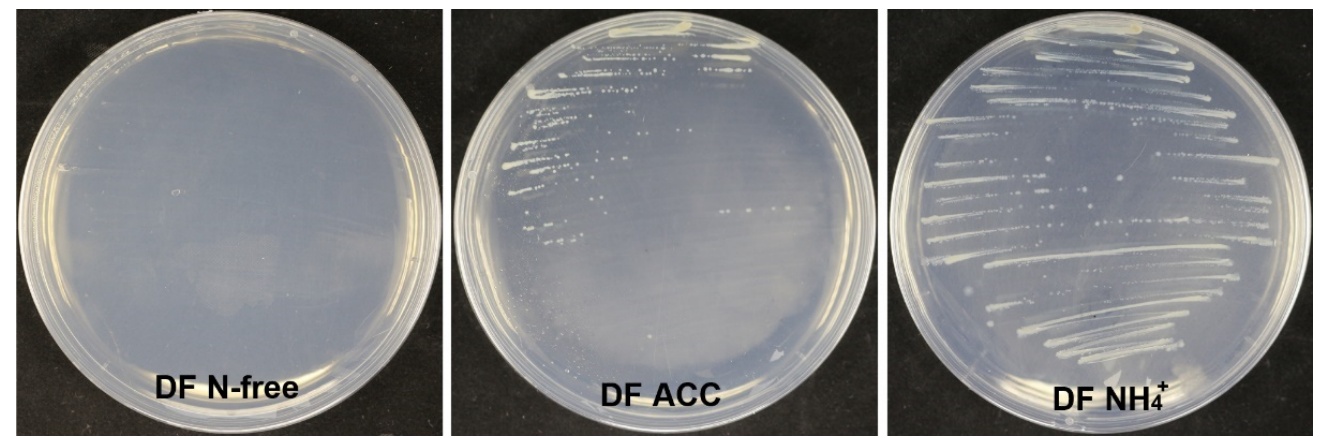

Figure 10. Growing on the DF medium with ACC (DF ACC) as the sole nitrogen source indicates that strain XL17 produces ACC deaminase. Strain XL17 cannot grow on the nitrogen-free DF medium (DF N-free) but grows well on the DF medium with ACC or ammonia $\left(\mathrm{DF} \mathrm{NH}_{4}^{+}\right)$as the sole nitrogen source. 


\subsection{Strain XL17 and XL17 CF Were Not Toxic to Rice Seeds and Seedlings}

To the test toxic or beneficial potentials on plants, rice seeds were inoculated with strain XL17 or treated with XL17 CF, streptomycin, or difenoconazole. XL17 and its CF had no effect on rice seed germination; streptomycin and difenoconazole slightly but not significantly inhibited seed germination. XL17 and its CF significantly increased rice shoot height and dry weight whereas streptomycin significantly reduced rice root length, shoot height, and dry weight, and difenoconazole significantly reduced root length and dry weight (Table 1).

Table 1. Effects of strain XL17 and its culture filtrate (CF) on rice seed germination and growth.

\begin{tabular}{lllll}
\hline Treatment & $\begin{array}{l}\text { Germination } \\
(\mathbf{\%})\end{array}$ & $\begin{array}{l}\text { Root Length } \\
(\mathbf{m m})\end{array}$ & $\begin{array}{l}\text { Shoot Height } \\
(\mathbf{m m})\end{array}$ & $\begin{array}{l}\text { Dry Weight } \\
(\mathbf{m g})\end{array}$ \\
\hline Control & $100 \pm 0.0^{\mathrm{a} *}$ & $45.6 \pm 0.0^{\mathrm{ab}}$ & $48.2 \pm 0.0^{\mathrm{b}}$ & $6.8 \pm 0.1^{\mathrm{b}}$ \\
XL17 & $100 \pm 0.0^{\mathrm{a}}$ & $45.9 \pm 0.0^{\mathrm{a}}$ & $50.8 \pm 0.0^{\mathrm{a}}$ & $7.4 \pm 0.1^{\mathrm{a}}$ \\
Streptomycin & $98.3 \pm 1.7^{\mathrm{a}}$ & $38.9 \pm 0.0^{\mathrm{d}}$ & $42.0 \pm 0.1^{\mathrm{c}}$ & $3.9 \pm 0.1^{\mathrm{d}}$ \\
Difenoconazole & $98.3 \pm 1.7^{\mathrm{a}}$ & $42.1 \pm 0.1^{\mathrm{c}}$ & $49.5 \pm 0.0^{\mathrm{ab}}$ & $6.3 \pm 0.2^{\mathrm{c}}$ \\
$10 \%$ CF & $100 \pm 0.0^{\mathrm{a}}$ & $44.5 \pm 0.0^{\mathrm{ab}}$ & $49.9 \pm 0.1^{\mathrm{a}}$ & $7.2 \pm 0.1^{\mathrm{a}}$ \\
$15 \%$ CF & $100 \pm 0.0^{\mathrm{a}}$ & $44.3 \pm 0.0^{\mathrm{b}}$ & $50.1 \pm 0.1^{\mathrm{a}}$ & $7.3 \pm 0.2^{\mathrm{a}}$ \\
$20 \%$ CF & $100 \pm 0.0^{\mathrm{a}}$ & $44.4 \pm 0.1^{\mathrm{b}}$ & $50.5 \pm 0.0^{\mathrm{a}}$ & $7.2 \pm 0.0^{\mathrm{a}}$ \\
\hline
\end{tabular}

*Values are mean \pm standard error of three replicates for each treatment. Different letters show significant difference at $p<0.05$.

Plant colonization by strain XL17 was determined from the rice seedlings under the gnotobiotic condition. At $7 \mathrm{~d}$ after inoculation to rice seeds, strain XL17 was recovered from rhizoplane and surface-sterilized roots and stems. The population of strain XL17 at rhizoplane, in roots, and in stems was $5.0 \times 10^{8} \pm 5.8 \times 10^{7}, 7.0 \times 10^{4} \pm 2.8 \times 10^{3}$, and $2.6 \times 10^{4} \pm 4.4 \times 10^{3} \mathrm{CFU} \mathrm{g}^{-1}$ fresh weight, respectively. Strain XL17 can live on and in plants.

\section{Discussion}

The $P$. fluorescens species complex is the most diverse complex within the genus Pseudomonas and consists of nine distinct phylogenomic subgroups: P. fluorescens, P. gesardii, $P$. fragi, P. mandelii, P. jessenii, P. koreensis, P. chlororaphis, P. protegens, and P. corrugata [62,63]. The $P$. corrugata subgroup contains both plant pathogens (such as P. corrugata and P. mediterranea) and plant growth-promoting bacteria (such as P. brassicacearum) [2,64]. Based on recent studies [1,2], our genomic analyses show that the P. corrugata subgroup contains at least 31 genomospecies.

We identified that the strain XL17 against Psa and B. cinerea belongs to P. bijieensis within the P. corrugata subgroup and the well-studied DAPG-producing strain 2P24 previously classified into species $P$. fluorescens $[54,55,65,66]$ belongs to a novel genomospecies mostly closely-related to $P$. bijieensis. P. bijieensis is a recently identified novel species based on the antifungal strain $\mathrm{L} 22-9^{\mathrm{T}}$ isolated from cornfield soil [67]. A previous functional study about $P$. bijieensis was on the previously misclassified P. fluorescens strain NBC275 (=Pf275), which was isolated from riverside soil and showed antifungal activity against plant pathogens B. cinerea, Alternaria solani, and Rhizoctonia solani and insect pathogens Metarhizium anisopliae and Beauveria bassiana [47]. A mutation generated by transposon in phlD completely abolished the antifungal activity of strain Pf275 [68]. Likewise, site-directed mutagenesis in phlD completely abolished DAPG production from strain 2P24 and its antagonistic activities against $R$. solani and bacterial pathogen Ralstonia solanacearum [65]. The amino acid sequences of PhlD (type III polyketide synthase) (accession no. WP_109753238) of all known P. bijieensis strains (L22-9 ${ }^{\mathrm{T}}$, XL17, Pf275, DR133, St290, and 43MFCvi1.1) are identical. We detected DAPG from XL17 CF showing the antimicrobial activities against B. cinerea and Psa. Collectively, these data indicate that DAPG is the key antifungal metabolite produced by P. bijieensis and strain $2 \mathrm{P} 24$. 
DAPG-producing $(p h l+)$ pseudomonads generally show higher plant-protecting activities than those of $p h l$ - biocontrol pseudomonads [69]. The phl operon for DAPG biosynthesis is mainly present in the genomes of some members of the P. corrugata subgroup and the P. protegens subgroup within the P. fluorescens species complex [70,71]. Melnyk et al. [51] revealed that the LPQ island can serve as a genetic marker for the plant-pathogenic life style of the P. corrugata subgroup and is associated with the presence of two small $(<10 \mathrm{~kb})$ genetic clusters with unknown functions (putative pathogenicity islets I and II) and the absence of the phl operon, Hrp1 T3SS, and the single "orphaned" T3SS effector gene hopAA. The phylogeny of the LPQ island [51] and phlD (Figure 7) is congruent with the species phylogeny (Figure 6) of the P. corrugata subgroup, in which the presence of the phl operon and the presence of the LPQ island are generally not overlapping except that genomospecies 25 and 28 contain both clusters (Figure 6). It is likely that the presence of the phl operon and the absence of the LPQ island can serve as the genetic marker for the plant-protection life style of the $P$. corrugata subgroup. Therefore, nine genomospecies within Clade 2 of the P. corrugata subgroup, i.e., P. bijieensis and strain 2P24-represented genomospecies 17, P. brassicacearum, P. kilonensis, P. thivervalensis, "P. ogarae subsp. ogarae", and genomospecies 8,13 , and 24 have a high probability to be effective biocontrol agents against plant pathogens.

Among the 11 genomospecies containing the phl operon, genomospecies 25 and 28 contain the LPQ island but no Hrp1 T3SS (Figure 6). Interestingly, the presence of the phl operon and the absence of the LPQ island happen to be in the presence of Hrp1 T3SS. That is, the presence of Hrp1 T3SS can serve as the genetic marker for the plant-protection life style of the P. corrugata subgroup. However, Hrp1 T3SS may not contribute to the known biocontrol activity. The deletion of $r s c C$ from the Hrp1 T3SS in strain 2P24 did not reduce the production of DAPG, HCN, and siderophores from strain 2P24 and its antagonistic ability against plant pathogens [54]. The function of the Hrp1 T3SS in the P. corrugata subgroup and the association between Hrp1 T3SS and the plant-commensal life style of the $P$. corrugata subgroup need further investigation.

DAPG is not the only antimicrobial metabolite from P. bijieensis and strain 2P24 contributing to their biocontrol activities. A mutation in P. bijieensis Pf275 and strain 2P24 did not abolish their biocontrol activities $[47,65]$. The gene clusters responsible for the biosynthesis of the pyoverdine siderophore, the linear lipopeptide (Val-Ala-Gln-Ala-ValAla-Pro-Thr), and the aryl polyene compound were also identified for their contribution to the biocontrol activity of P. bijieensis Pf275 [47,72]. These gene clusters are also present in the genome of the other P. bijieensis strains and strain 2P24 and may also contribute to their biocontrol activities. Although XL17 produced pyoverdine siderophores on King's B medium, siderophore production may not contribute to the antimicrobial activities detected on the iron sufficient PDA and LB media.

Cyclic lipopeptides produced by plant-associated pathogenic and beneficial Pseudomonas are biosurfactants involved in motility, surface attachment, biofilm regulation, virulence, antimicrobial activities, and the induction of plant resistance [73,74]. Although the biosynthetic gene clusters for cyclic lipopeptides were not clearly identified in P. bijieensis, viscosin- and orfamide-like lipopeptides were detected by MALDI-TOF-MS from XL17 cells. Viscosins show broad-spectrum antimicrobial activities against fungi, Gram-positive bacteria, and Gram-negative bacteria but not Pseudomonas pathogens [73]. Orfamides show antifungal activities but no antibacterial activities [73]. Cyclic lipopeptides of the viscosin family and orfamide family may participate in XL17 against $B$. cinerea.

Our genomic analyses and metabolic analyses on strain XL17 and previous studies on potent biocontrol pseudomonads [69,73,74], including strains Pf275 and 2P24 [65,68], strongly suggest that DAPG and lipopeptides are the key antimicrobial metabolites from strain XL17 to breach the cell envelopes of Psa and B. cinerea. On the other hand, DAPG and cyclic lipopeptides produced by plant-associated pseudomonads [73-77] may be toxic to plants $[74,78]$. Thus, we did a phytotoxic test and demonstrated that strain XL17 and its CF were not toxic to rice seeds and seedlings but increased rice shoot height and dry 
weight. Therefore, XL17 and its CF can promote plant growth. The bacterial production of IAA and ACC deaminase may be involved in this plant growth-promotion [79].

Strain XL17 showed no chitinase activity and much weaker $\beta-1,3$-glucanase and protease activities compared with Paenibacillus peoriae CGMCC $1.3761^{\mathrm{T}}$, which showed strong hydrolytic enzyme activities but no antagonistic activity against $B$. cinerea [24]. It is likely that hydrolytic enzymes from strain XL17 may not play an important role in breaching the cell envelope of B. cinerea.

Our initial intention was to screen biocontrol endophytes, which are competent plant colonizers and adapt to plant immune response to form a mutualistic association with plants [24]; we found P. bijieensis XL17 from a surface-sterilized rape crown gall. However, P. bijieensis $\mathrm{L} 22-9^{\mathrm{T}}$ and Pf 275 and the closely related strain $2 \mathrm{P} 24$, which also show potent biocontrol activities, were isolated from soil $[65,67,68]$. Our genomic analyses and previous molecular studies on strains Pf275 and 2P24 $[65,68]$ revealed that genetic lineage with the conserved $p h l$ operon and NRPS gene clusters rather than the original source is the key to find potent biocontrol agents. Most phlD-carrying strains within Clade 2 of the P. corrugata subgroup (Figure 6) are potential biocontrol agents. Lipopeptide families also determine the plant-pathogenic or plant-protecting behavior of the strains within the P. corrugata subgroup $[73,74]$. Therefore, we propose a rapid approach to identify effective biocontrol pseudomonads belonging to the $P$. corrugata subgroup after screening out a potent antimicrobial bacterium. First, the phylogenetic analysis of nearly complete $16 \mathrm{~S}$ rRNA gene sequences identifies an antimicrobial strain within the P. corrugata subgroup. Second, PCR amplification and sequencing of the phlD sequence identifies a DAPG producer. Third, MALDI-TOF-MS identifies a lipopeptide producer.

\section{Conclusions}

Our phenotypic, genomic, and metabolic analyses identified that P. bijieensis XL17 producing DAPG and lipopeptides are able to control bacterial canker and gray mold pathogens of kiwifruit. The conserved presence of the phl operon for DAPG biosynthesis and the NRPS gene clusters for lipopeptide biosynthesis other than the LPQ island determines the biocontrol strength of P. bijieensis and its relatives within the P. corrugata subgroup against fungal and bacterial phytopathogens.

Supplementary Materials: The following supporting information can be downloaded at: https:/ / www.mdpi.com/article/10.3390/microorganisms10020425/s1, Figure S1: Compact view of gene clusters for biosynthesis of secondary metabolites identified by antiSMASH version 6.0 (https: / / antismash. secondarymetabolites.org/, accessed on 10 October 2021) using relaxed detection strictness from whole genome sequences of Pseudomonas bijieensis strains and the neighboring genomospecies strain Pseudomonas sp. 2P24.; Table S1: Digital DNA-DNA hybridization (dDDH) values between genome pairs of strains within Pseudomonas corrugata subgroup; Table S2: Digital DNA-DNA hybridization $(\mathrm{dDDH})$ values between genome pairs of strains belonging to "Pseudomonas ogarae".

Author Contributions: M.A.A., J.L., D.D., B.L. and Q.A. contributed to conceptualization; J.J. and J.Z. (Jie Zhu) contributed to microbial and plant materials; M.A.A., T.A., S.H., J.A.A., J.Z. (Jiannan Zhang), T.X. and Q.A. contributed to investigation; M.A.A. and Q.A. contributed to data analysis; M.A.A., J.L., T.A., S.H., J.A.A. and Q.A. contributed to manuscript preparation; J.L., D.D., B.L. and Q.A. contributed to supervision; J.L., D.D., J.J., J.Z. (Jie Zhu), S.H., J.A.A., B.L. and Q.A. contributed to funding acquisition. All authors have read and agreed to the published version of the manuscript.

Funding: This research was funded by the Key Research and Development Program of Zhejiang Province, China (2020C02006), the Zhejiang Provincial Natural Science Foundation of China (LY19C010007), the Shanghai Agricultural Basic Research Project (2019-02-08-00-08-F01150), the State Key Laboratory for Managing Biotic and Chemical Threats to the Quality and Safety of Agro-products, China (2010DS700124-ZZ2014;-KF202101), and the Taif University Researchers Supporting Project (TURSP-2020/142), Taif University, Saudi Arabia. The APC was funded by the Taif University Researchers Supporting Project (TURSP-2020/142).

Institutional Review Board Statement: Not applicable. 
Informed Consent Statement: Not applicable.

Data Availability Statement: Not applicable.

Conflicts of Interest: The authors declare no conflict of interest.

\section{References}

1. Girard, L.; Lood, C.; Höfte, M.; Vandamme, P.; Rokni-Zadeh, H.; van Noort, V.; Lavigne, R.; De Mot, R. The ever-expanding Pseudomonas genus: Description of 43 new species and partition of the Pseudomonas putida group. Microorganisms 2021, 9, 1766. [CrossRef] [PubMed]

2. Garrido-Sanz, D.; Redondo-Nieto, M.; Martin, M.; Rivilla, R. Comparative genomics of the Pseudomonas corrugata subgroup reveals high species diversity and allows the description of Pseudomonas ogarae sp. nov. Microb. Genom. 2021, 7, 000593. [CrossRef] [PubMed]

3. Xin, X.F.; Kvitko, B.; He, S.Y. Pseudomonas syringae: What it takes to be a pathogen. Nat. Rev. Microbiol. 2018, 16, 316-328. [CrossRef] [PubMed]

4. Nishiyama, I. Fruits of the Actinidia genus. Adv. Food Nutr. Res. 2007, 52, 293-324.

5. Richardson, D.P.; Ansell, J.; Drummond, L.N. The nutritional and health attributes of kiwifruit: A review. Eur. J. Nutr. 2018, 57, 2659-2676. [CrossRef]

6. Scortichini, M.; Marcelletti, S.; Ferrante, P.; Petriccione, M.; Firrao, G. Pseudomonas syringae pv. actinidiae: A re-emerging, multi-faceted, pandemic pathogen. Mol. Plant. Pathol. 2012, 13, 631-640. [CrossRef]

7. Vanneste, J.L. The Scientific, Economic, and Social Impacts of the New Zealand outbreak of bacterial canker of Kiwifruit (Pseudomonas syringae pv. actinidiae). Annu. Rev. Phytopathol. 2017, 55, 377-399. [CrossRef]

8. Dai, Y.; Wang, Z.; Leng, J.; Sui, Y.; Jiang, M.; Wisniewski, M.; Liu, J.; Wang, Q. Eco-friendly management of postharvest fungal decays in kiwifruit. Crit. Rev. Food Sci. Nutri. 2021, in press. [CrossRef]

9. Michailides, T.J.; Elmer, P.A.G. Botrytis gray mold of kiwifruit caused by Botrytis cinerea in the United States and New Zealand Plant Dis. 2000, 84, 208-223. [CrossRef]

10. Cameron, A.; Sarojini, V. Pseudomonas syringae pv. actinidiae: Chemical control, resistance mechanisms and possible alternatives. Plant Pathol. 2014, 63, 1-11. [CrossRef]

11. Vanneste, J.L.; Cornish, D.A.; Yu, J.; Boyd, R.J.; Morris, C.E. Isolation of copper and streptomycin resistant phytopathogenic Pseudomonas syringae from lakes and rivers in the central North Island of New Zealand. N. Z. Plant Prot. 2008, 61, 80-85. [CrossRef]

12. Fan, F.; Hamada, M.S.; Li, N.; Li, G.Q.; Luo, C.X. Multiple fungicide resistance in Botrytis cinerea from greenhouse Strawberries in Hubei province, China. Plant Dis. 2017, 101, 601-606. [CrossRef] [PubMed]

13. Rupp, S.; Weber, R.W.; Rieger, D.; Detzel, P.; Hahn, M. Spread of Botrytis cinerea strains with multiple fungicide resistance in German horticulture. Front. Microbiol. 2016, 7, 2075. [CrossRef] [PubMed]

14. Abbey, J.A.; Percival, D.; Abbey, L.; Asiedu, S.K.; Prithiviraj, B.; Schilder, A. Biofungicides as alternative to synthetic fungicide control of grey mould (Botrytis cinerea)—Prospects and challenges. Biocontrol. Sci. Technol. 2019, 29, 207-228. [CrossRef]

15. Mauri, S.; Cellini, A.; Buriani, G.; Donati, I.; Costa, G.; Spinelli, F. Optimization of cultural practices to reduce the development of Pseudomonas syringae pv. actinidiae, causal agent of the bacterial canker of kiwifruit. J. Berry Res. 2016, 6, 355-371.

16. Stefani, E.; Giovanardi, D. Dissemination of Pseudomonas syringae pv. actinidiae through pollen and its epiphytic life on leaves and fruits. Phytopathol. Mediterr. 2011, 50, 489-496.

17. Vanneste, J.L.; Yu, J.; Cornish, D.A.; Max, S.; Clark, G. Presence of Pseudomonas syringae pv. actinidiae, the causal agent of bacterial canker of kiwifruit, on symptomatic and asymptomatic tissues of kiwifruit. N. Z. Plant Prot. 2011, 64, 241-245. [CrossRef]

18. Donati, I.; Cellini, A.; Sangiorgio, D.; Vanneste, J.L.; Scortichini, M.; Balestra, G.M.; Spinelli, F. Pseudomonas syringae pv. actinidiae: Ecology, infection dynamics and disease epidemiology. Microb. Ecol. 2020, 80, 81-102. [CrossRef]

19. Figueira, D.; Garcia, E.; Ares, A.; Tiago, I.; Veríssimo, A.; Costa, J. Genetic diversity of Pseudomonas syringae pv. actinidiae: Seasonal and spatial population dynamics. Microorganisms 2020, 8, 931. [CrossRef]

20. Gao, X.; Huang, Q.; Zhao, Z.; Han, Q.; Ke, X.; Qin, H.; Huang, L. Studies on the infection, colonization, and movement of Pseudomonas syringae pv. actinidiae in kiwifruit tissues using a GFPuv-labeled strain. PLoS ONE 2016, 11, e0151169. [CrossRef]

21. Spinelli, F.; Donati, I.; Vanneste, J.L.; Costa, M.; Costa, G. Real time monitoring of the interactions between Pseudomonas syringae pv. actinidiae and Actinidia species. Acta Hortic. 2011, 913, 461-466. [CrossRef]

22. Elad, Y.; Pertot, I.; Prado, A.M.C.; Stewart, A. Plant hosts of Botrytis spp. In Botrytis—The Fungus, the Pathogen and Its Management in Agricultural Systems; Elad, Y., Fillinger, S., Eds.; Springer: Cham, Switzerland, 2016; pp. 413-486.

23. Hardoim, P.R.; van Overbeek, L.S.; Berg, G.; Pirttilä, A.M.; Compant, S.; Campisano, A.; Döring, M.; Sessitsch, A. The hidden world within plants: Ecological and evolutionary considerations for defining functioning of microbial endophytes. Microbiol. Mol. Biol. Rev. 2015, 79, 293-320. [CrossRef] [PubMed]

24. Ali, M.A.; Lou, Y.; Hafeez, R.; Li, X.; Hossain, A.; Xie, T.; Lin, L.; Li, B.; Yin, Y.; Yan, J.; et al. Functional analysis and genome mining reveal high potential of biocontrol and plant growth promotion in nodule-inhabiting bacteria within Paenibacillus polymyxa complex. Front. Microbiol. 2021, 11, 618601. [CrossRef] [PubMed]

25. Faretra, F.; Antonacci, E. Production of apothecia of Botryotinia fuckeliana (de Bary) Whetz. under controlled environmental conditions. Phytopathol. Medit. 1987, 26, 29-35. 
26. Hossain, A.; Masum, M.M.I.; Wu, X.; Abdallah, Y.; Ogunyemi, S.O.; Wang, Y.; Sun, G.; Li, B.; An, Q. Screening of Bacillus strains in biocontrol of pathogen Dickeya dadantii causing stem and root rot disease of sweet potato. Biocontrol Sci. Technol. 2020, 30, 1180-1198. [CrossRef]

27. Lee, H.J.; Choi, G.J.; Cho, K.Y. Correlation of lipid peroxidation in Botrytis cinerea caused by Dicarboximide fungicides with their fungicidal activity. J. Agric. Food Chem. 1998, 46, 737-741. [CrossRef]

28. Koh, Y.J.; Lee, D.H.; Shin, J.S.; Hur, J.S. Chemical and cultural control of bacterial blossom blight of kiwifruit caused by Pseudomonas syringae in Korea. N. Z. J. Crop Hortic. Sci. 2001, 29, 29-34. [CrossRef]

29. Ali, M.A.; Ren, H.; Ahmed, T.; Luo, J.; An, Q.; Qi, X.; Li, B. Antifungal effects of rhizospheric Bacillus species against Bayberry twig blight pathogen Pestalotiopsis versicolor. Agronomy 2020, 10, 1811. [CrossRef]

30. Liu, J.; Sui, Y.; Chen, H.; Liu, Y.; Liu, Y. Proteomic analysis of kiwifruit in response to the postharvest pathogen, Botrytis cinerea. Front. Plant. Sci. 2018, 9, 158. [CrossRef]

31. Zhang, C.; Imran, M.; Xiao, L.; Hu, Z.; Li, G.; Zhang, F.; Liu, X. Difenoconazole resistance shift in Botrytis cinerea from Tomato in China associated with inducible expression of CYP51. Plant Dis. 2021, 105, 400-407. [CrossRef]

32. Tamura, K.; Peterson, D.; Peterson, N.; Stecher, G.; Nei, M.; Kumar, S. MEGA5: Molecular evolutionary genetics analysis using maximum likelihood, evolutionary distance, and maximum parsimony methods. Mol. Biol. Evol. 2011, 28, 2731-2739. [CrossRef] [PubMed]

33. Lim, H.J.; Lee, E.H.; Yoon, Y.; Chua, B.; Son, A. Portable lysis apparatus for rapid single-step DNA extraction of Bacillus subtilis. J. Appl. Microbiol. 2016, 120, 379-387. [CrossRef] [PubMed]

34. Li, R.; Li, Y.; Kristiansen, K.; Wang, J. SOAP: Short oligonucleotide alignment program. Bioinformatics 2008, 24, 713-714. [CrossRef] [PubMed]

35. Bankevich, A.; Nurk, S.; Antipov, D.; Gurevich, A.A.; Dvorkin, M.; Kulikov, A.S.; Lesin, V.M.; Nikolenko, S.I.; Pham, S.; Prjibelski, A.D.; et al. SPAdes: A new genome assembly algorithm and its applications to single-cell sequencing. J. Comput. Biol. 2012, 19, 455-477. [CrossRef] [PubMed]

36. Simpson, J.T.; Wong, K.; Jackman, S.D.; Schein, J.E.; Jones, S.J.; Birol, I. ABySS: A parallel assembler for short read sequence data. Genome Res. 2009, 19, 1117-1123. [CrossRef]

37. Lin, S.H.; Liao, Y.C. CISA: Contig integrator for sequence assembly of bacterial genomes. PLoS ONE 2013, 8, e60843. [CrossRef] [PubMed]

38. Tatusova, T.; DiCuccio, M.; Badretdin, A.; Chetvernin, V.; Nawrocki, E.P.; Zaslavsky, L.; Lomsadze, A.; Pruitt, K.D.; Borodovsky, M.; Ostell, J. NCBI prokaryotic genome annotation pipeline. Nucleic Acids Res. 2016, 44, 6614-6624. [CrossRef]

39. Meier-Kolthoff, J.P.; Auch, A.F.; Klenk, H.P.; Göker, M. Genome sequence-based species delimitation with confidence intervals and improved distance functions. BMC Bioinform. 2013, 14, 60. [CrossRef]

40. Blin, K.; Shaw, S.; Kloosterman, A.M.; Charlop-Powers, Z.; van Wezel, G.P.; Medema, M.H.; Weber, T. antiSMASH 6.0: Improving cluster detection and comparison capabilities. Nucleic Acids Res. 2021, 49, W29-W35. [CrossRef]

41. Zhao, Y.; Wu, J.; Yang, J.; Sun, S.; Xiao, J.; Yu, J. PGAP: Pan-genomes analysis pipeline. Bioinformatics 2012, 28, 416-418. [CrossRef]

42. Katoh, K.; Kuma, K.I.; Toh, H.; Miyata, T. MAFFT version 5: Improvement in accuracy of multiple sequence alignment. Nucleic Acids Res. 2005, 33, 511-518. [CrossRef] [PubMed]

43. Castresana, J. Selection of conserved blocks from multiple alignments for their use in phylogenetic analysis. Mol. Biol. Evol. 2000, 17, 540-552. [CrossRef] [PubMed]

44. Nguyen, L.T.; Schmidt, H.A.; Von Haeseler, A.; Minh, B.Q. IQ-TREE: A fast and effective stochastic algorithm for estimating maximum-likelihood phylogenies. Mol. Biol. Evol. 2014, 32, 268-274. [CrossRef]

45. Letunic, I.; Bork, P. Interactive tree of life (iTOL) v5: An online tool for phylogenetic tree display and annotation. Nucleic Acids Res. 2021, 49, W293-W296. [CrossRef] [PubMed]

46. Raaijmakers, J.M.; Weller, D.M.; Thomashow, L.S. Frequency of antibiotic-producing Pseudomonas spp. in natural environments. Appl. Environ. Microbiol. 1997, 63, 881-887. [CrossRef]

47. Dutta, S.; Yu, S.M.; Jeong, S.C.; Lee, Y.H. High throughput analysis of genes involved in biocontrol performance of Pseudomonas fluorescens NBC275 against gray mold. J. Appl. Microbiol. 2019, 128, 265-279. [CrossRef] [PubMed]

48. Sarwar, M.; Kremer, R.J. Determination of bacterially derived auxins using a microplate method. Lett. Appl. Microbiol. 1995, 20, $282-285$. [CrossRef]

49. Penrose, D.M.; Glick, B.R. Methods for isolating and characterizing ACC deaminase-containing plant growth-promoting rhizobacteria. Physiol. Plant. 2003, 118, 10-15. [CrossRef]

50. OECD. Terrestrial plants, growth test. In OECD Guideline for Testing of Chemicals No. 208; OECD: Paris, France, $1984 ;$ pp. 1-21.

51. Melnyk, R.A.; Hossain, S.S.; Haney, C.H. Convergent gain and loss of genomic islands drive lifestyle changes in plant-associated Pseudomonas. ISME J. 2019, 13, 1575-1588. [CrossRef]

52. Meier-Kolthoff, J.P.; Hahnke, R.L.; Petersen, J.; Scheuner, C.; Michael, V.; Fiebig, A.; Rohde, C.; Rohde, M.; Fartmann, B.; Goodwin, L.A.; et al. Complete genome sequence of DSM 30083T the type strain $\left(\mathrm{U} 5 / 41^{\mathrm{T}}\right)$ of Escherichia coli and a proposal for delineating subspecies in microbial taxonomy. Stand. Genom. Sci. 2014, 9, 2. [CrossRef]

53. Licciardello, G.; Bertani, I.; Steindler, L.; Bella, P.; Venturi, V. Pseudomonas corrugata contains a conserved N-acyl homoserine lactone quorum sensing system; its role in tomato pathogenicity and tobacco hypersensitivity response. FEMS Microbiol. Ecol. 2007, 61, 222-234. [CrossRef] [PubMed] 
54. Liu, P.; Wei, Z.; Zhang, L.Q.; Liu, X.; Wei, H.L. Supramolecular structure and functional analysis of the type III secretion system in Pseudomonas fluorescens 2P24. Front. Plant Sci. 2016, 6, 1190. [CrossRef] [PubMed]

55. Wang, J.; Luo, Y.; Gu, Y.; Wei, H.L. Characterization of the SPI-1 Type III secretion system in Pseudomonas fluorescens 2P24. Front. Microbiol. 2021, 12, 749037. [CrossRef] [PubMed]

56. Gerard, J.; Lloyd, R.; Barsby, T.; Haden, P.; Kelly, M.T.; Andersen, R.J. Massetolides A-H, antimycobacterial cyclic depsipeptides produced by two pseudomonads isolated from marine habitats. J. Nat. Prod. 1997, 60, 223-229. [CrossRef]

57. Nielsen, T.H.; Christophersen, C.; Anthoni, U.; Sørensen, J. Viscosinamide, a new cyclic depsipeptide with surfactant and antifungal properties produced by Pseudomonas fluorescens DR54. J. Appl. Microbiol. 1999, 87, 80-90. [CrossRef]

58. De Bruijn, I.; De Kock, M.J.; Yang, M.; De Waard, P.; Van Beek, T.A.; Raaijmakers, J.M. Genome-based discovery, structure prediction and functional analysis of cyclic lipopeptide antibiotics in Pseudomonas species. Mol. Microbiol. 2007, 63, 417-428. [CrossRef]

59. D’aes, J.; Kieu, N.P.; Léclère, V.; Tokarski, C.; Olorunleke, F.E.; De Maeyer, K.; Jacques, P.; Höfte, M.; Ongena, M. To settle or to move? The interplay between two classes of cyclic lipopeptides in the biocontrol strain Pseudomonas CMR12a. Environ. Microbiol. 2014, 16, 2282-2300. [CrossRef]

60. Gross, H.; Stockwell, V.O.; Henkels, M.D.; Nowak-Thompson, B.; Loper, J.E.; Gerwick, W.H. The genomisotopic approach: A systematic method to isolate products of orphan biosynthetic gene clusters. Chem. Biol. 2007, 14, 53-63. [CrossRef]

61. Ma, Z.; Geudens, N.; Kieu, N.P.; Sinnaeve, D.; Ongena, M.; Martins, J.C.; Höfte, M. Biosynthesis, chemical structure, and structure-activity relationship of orfamide lipopeptides produced by Pseudomonas protegens and related species. Front. Microbiol. 2016, 7, 382. [CrossRef]

62. Garrido-Sanz, D.; Meier-Kolthoff, J.P.; Göker, M.; Martín, M.; Rivilla, R.; Redondo-Nieto, M. Genomic and genetic diversity within the Pseudomonas fluorescens complex. PLoS ONE 2016, 11, e0153733. [CrossRef]

63. Lalucat, J.; Mulet, M.; Gomila, M.; García-Valdés, E. Genomics in bacterial taxonomy: Impact on the genus Pseudomonas. Genes (Basel) 2020, 11, 139. [CrossRef] [PubMed]

64. Catara, V. Pseudomonas corrugata: Plant pathogen and/or biological resource? Mol. Plant Pathol. 2007, 8, 233-244. [CrossRef] [PubMed]

65. Wei, H.L.; Zhou, H.Y.; Zhang, L.Q.; Wang, Y.; Tang, W.H. Experimental evidence on the functional agent of 2,4diacetylphloroglucinol in biocontrol activity of Pseudomonas fluorescens 2P24. Acta Microbiol. Sin. 2004, 44, 663-666.

66. Zhang, W.; Zhao, Z.; Zhang, B.; Wu, X.G.; Ren, Z.G.; Zhang, L.Q. Posttranscriptional regulation of 2,4-Diacetylphloroglucinol production by GidA and TrmE in Pseudomonas fluorescens 2P24. Appl. Environ. Microbiol. 2014, 80, 3972-3981. [CrossRef]

67. Liang, J.; Wang, S.; Yiming, A.; Fu, L.; Ahmad, I.; Chen, G.; Zhu, B. Pseudomonas bijieensis sp. nov., isolated from cornfield soil. Int. J. Syst. Evol. Microbiol. 2019, 71, 004676. [CrossRef]

68. Dutta, S.; Yu, S.M.; Nagendran, R.; Jeong, S.C.; Lee, Y.H. Complete genome sequencing of Pseudomonas fluorescens NBC275, a biocontrol agent against fungal pathogens of plants and insects. Korean J. Microbiol. 2019, 55, 157-159.

69. Rezzonico, F.; Zala, M.; Keel, C.; Duffy, B.; Moënne-Loccoz, Y.; Défago, G. Is the ability of biocontrol fluorescent pseudomonads to produce the antifungal metabolite 2,4-diacetylphloroglucinol really synonymous with higher plant protection? New Phytol. 2007, 17, 861-872. [CrossRef]

70. Almario, J.; Bruto, M.; Vacheron, J.; Prigent-Combaret, C.; Moënne-Loccoz, Y.; Muller, D. Distribution of 2,4-Diacetylphloroglucinol biosynthetic genes among the Pseudomonas spp. reveals unexpected polyphyletism. Front. Microbiol. 2017, 8, 1218. [CrossRef]

71. Gutiérrez-García, K.; Neira-González, A.; Pérez-Gutiérrez, R.M.; Granados-Ramírez, G.; Zarraga, R.; Wrobel, K.; Barona-Gómez, F.; Flores-Cotera, L.B. Phylogenomics of 2,4-Diacetylphloroglucinol-producing Pseudomonas and novel antiglycation endophytes from Piper auritum. J. Nat. Prod. 2017, 80, 1955-1963. [CrossRef]

72. Dutta, S.; Yu, S.M.; Lee, Y.H. Assessment of the contribution of antagonistic secondary metabolites to the antifungal and biocontrol activities of Pseudomonas fluorescens NBC275. Plant Pathol. J. 2020, 36, 491-496. [CrossRef]

73. Geudens, N.; Martins, J.C. Cyclic lipodepsipeptides from Pseudomonas spp.-biological Swiss-army knives. Front. Microbiol. 2018, 9, 1867. [CrossRef] [PubMed]

74. Girard, L.; Höfte, M.; De Mot, R. Lipopeptide families at the interface between pathogenic and beneficial Pseudomonas-plant interactions. Crit. Rev. Microbiol. 2020, 46, 397-419. [CrossRef] [PubMed]

75. Julian, W.T.; Vasilchenko, A.V.; Shpindyuk, D.D.; Poshvina, D.V.; Vasilchenko, A.S. Bacterial-derived plant protection metabolite 2,4-diacetylphloroglucinol: Effects on bacterial cells at inhibitory and subinhibitory concentrations. Biomolecules 2020, 11, 13. [CrossRef] [PubMed]

76. De Souza, J.T.; Arnould, C.; Deulvot, C.; Lemanceau, P.; Gianinazzi-Pearson, V.; Raaijmakers, J.M. Effect of 2, 4-diacetylphloroglucinol on Pythium: Cellular responses and variation in sensitivity among propagules and species. Phytopathology 2003, 93, 966-975. [CrossRef]

77. Schouten, A.; Maksimova, O.; Cuesta-Arenas, Y.; Van Den Berg, G.; Raaijmakers, J.M. Involvement of the ABC transporter BcAtrB and the laccase BcLCC2 in defence of Botrytis cinerea against the broad-spectrum antibiotic 2,4-diacetylphloroglucinol. Environ. Microbiol. 2008, 10, 1145-1157. [CrossRef] 
78. Chae, D.H.; Kim, D.R.; Cho, G.; Moon, S.; Kwak, Y.S. Genome-wide investigation of 2,4-Diacetylphloroglucinol protection genes in Arabidopsis thaliana. Mol. Plant Microbe Interact. 2020, 33, 1072-1079. [CrossRef]

79. Glick, B.R. Bacteria with ACC deaminase can promote plant growth and help to feed the world. Microbiol. Res. 2014, 169, 30-39. [CrossRef] 